\title{
Emerging magnesium-based biomaterials for orthopedic implantation
}

1 Aidin Bordbar-Khiabani MSC

Researcher, Bioengineering Research Group, Nanotechnology and Advanced Materials Department, Materials and Energy Research Center, Tehran, Iran (corresponding author: a.bordbar@merc.ac.ir, aidinbordbar@gmail.com)

2 Benyamin Yarmand PhD

Assistant Professor, Bioengineering Research Group, Nanotechnology and Advanced Materials Department, Materials and Energy Research Center, Tehran, Iran

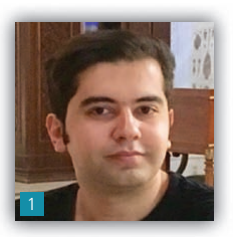

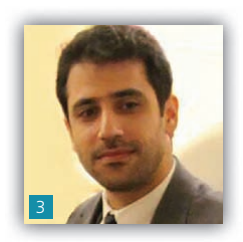

3 Masoud Mozafari PhD

Assistant Professor, Bioengineering Research Group, Nanotechnology and Advanced Materials Department, Materials and Energy Research Center, Tehran, Iran; Department of Tissue Engineering and Regenerative Medicine, Faculty of Advanced Technologies in Medicine, Iran University of Medical Sciences, Tehran, Iran

Orthopedic implants, such as those made of stainless steel, cobalt (Co)-based alloys and titanium (Ti) alloys, are commonly used to stabilize, protect, improve, replace or regenerate damaged musculoskeletal tissues both anatomically and functionally in millions of bone injury patients. The biggest drawback of these metallic biomaterials is their non-degradability in the body environment. Magnesium (Mg) and magnesium-based alloys are a new generation of degradable implant materials that have attracted great attention in the past 10 years. There are several advantages of magnesium-based alloys for orthopedic application over other metallic biomaterials. First, magnesium is an essential element for many biological activities, including enzymatic reactions, the formation of apatite and bone cell adsorption. Second, their mechanical properties, including density, elastic modulus and compressive yield strength, are much closer to those of natural bone, and, therefore, they can avoid the stressshielding effect. Third, magnesium alloys can eliminate the necessity of a second surgery to remove permanent bone implants. Recent results show that alloying of magnesium with aluminum (Al), zinc ( $\mathrm{Zn})$, calcium (Ca), zirconium (Zr), yttrium $(\mathrm{Y})$ and rare-earth elements can significantly improve its corrosion resistance and mechanical strength. This paper reviews and compares the mechanical properties, corrosion resistance and biocompatibility of currently researched magnesium-based alloys for use in medical implant applications.

\section{Introduction}

Historically speaking, the concept of implanting foreign objects into the human body has arisen remarkably. Biomaterial science involves the study of the properties and composition of materials and the physiological and biological interactions in which they participate. ${ }^{1}$ Since the late eighteenth century, biomaterials have been used in joint replacements, bone plates, bone cement, artificial ligaments, artificial tendons, dental implants, blood vessel prostheses, heart valves, cardiovascular stents and artificial skin. $^{2}$ The development of biomaterials has three stages: inert biomaterials, biodegradable biomaterials and regenerative biomaterials. ${ }^{3}$ Inert biomaterials function mainly to maintain local system integrity and have limited tissue response. Degradable biomaterials can be degraded and absorbed by local tissues over a certain amount of time. Regenerative biomaterials should not only have the basic characteristics of a biomaterial, but also be able to induce and promote the self-healing of tissue. ${ }^{2}$ Based on material composition, the most common classes of biomaterials include ceramic materials, polymer materials, metallic materials and composite materials. ${ }^{3}$
Metallic materials continue to play an essential role as biomaterials in assisting with the repair or replacement of bone tissue that has become diseased or damaged. Metals are more suitable for loadbearing applications compared with ceramics or polymers because of their high mechanical strength as well as high fracture toughness. ${ }^{4}$ In the past few decades, non-degradable metals - namely, titanium (Ti), titanium alloys, stainless steel, nitinol (nickel (Ni)-titanium alloy) and cobalt (Co)-based alloys - have been the most widely used biomaterials for medical implant applications. ${ }^{5-9}$ However, the major limitations of these currently applied metals lie in their undesirable mechanical properties, leading to the serious stress-shielding problem, ${ }^{10}$ and the non-degradability of these permanent materials, thus requiring a second surgery for implant removal, as well as the release of toxic ions through corrosion or the wear process, such as titanium and cobalt particles, which could even cause inflammatory osteolysis. ${ }^{11-13}$ Therefore, an urgent necessity for the development of next-generation implant biomaterials has arisen. Recently, biodegradable metallic materials, such as iron (Fe), zinc ( $\mathrm{Zn})$, zinc alloys, magnesium $(\mathrm{Mg})$ and magnesium alloys, have attracted a growing interest and are intensively investigated. ${ }^{14-17}$ 
Emerging Materials Research Volume 8 Issue EMR3
Emerging magnesium-based biomaterials

for orthopedic implantation

Bordbar-Khiabani, Yarmand and Mozafari
Magnesium is a very attractive biodegradable material with good mechanical properties, suitable biocompatibility and low thrombogenicity. ${ }^{16,17}$ The densities of the biomedical titanium alloy Ti6Al4V and stainless steel $316 \mathrm{~L}$ are 4.47 and $7.79 \mathrm{~g} / \mathrm{cm}^{3}$, respectively, while the densities of pure magnesium $\left(1.738 \mathrm{~g} / \mathrm{cm}^{3}\right)$ and magnesium-based alloys $\left(1 \cdot 75-1 \cdot 85 / \mathrm{cm}^{3}\right)$ are very similar to that of human cortical bone $\left(1.75 \mathrm{~g} / \mathrm{cm}^{3}\right){ }^{18}$ The history of application of magnesium as a degradable biomaterial dates back to the late nineteenth century. Huse ${ }^{19}$ in 1878 reported the first use of pure magnesium wires as ligatures. In 1981, a 3-month-old child with proliferating hemangioma on its face, throat and shoulders was cured after 20 months of treatment by insertion of the magnesium arrows (Figure 1). ${ }^{20}$ The major limitation of pure magnesium is its low corrosion resistance. Low corrosion resistance results in the rapid release of degradation products. A high rate of degradation under physiological conditions can cause a reduction in the
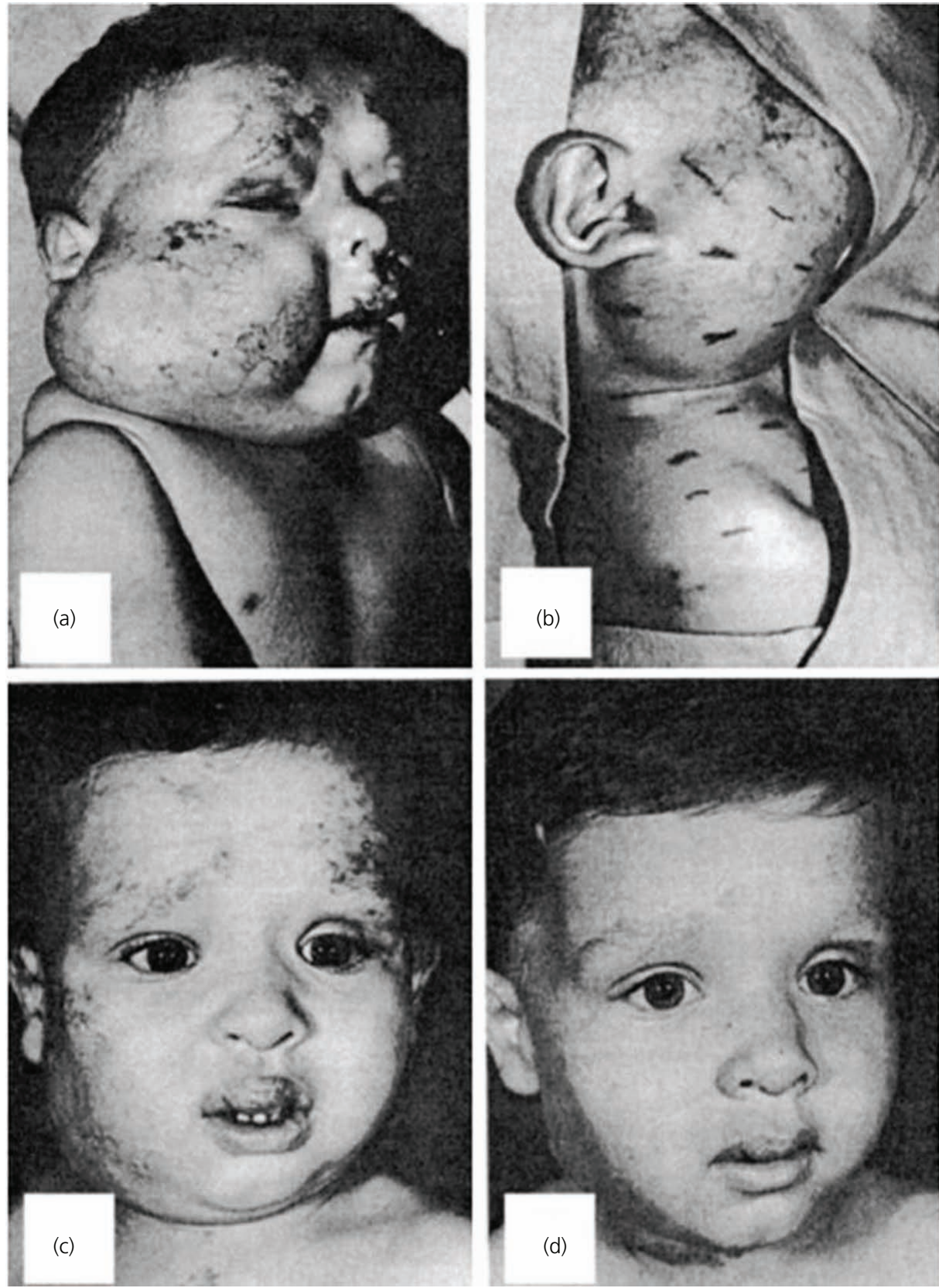

Figure 1. (a) A 3-month-old child with proliferating hemangioma of the face, throat and shoulders. (b) The same patient as in (a); the incisions for the insertion of the magnesium arrows are marked with ink on the skin. (c) After 3 weeks, the treatment was repeated, and, 9 months after the beginning of the treatment, a significant reduction of the hemangioma could be observed. (d) After an additional insertion of magnesium arrows at 3 months, the face of the 2 -year-old child became almost normal at 20 months after starting the magnesium treatment ${ }^{20}$ 
mechanical integrity of the implant before the bone or tissue is sufficiently healed. Therefore, due to the high corrosion rate, very fast degradation rate and lower mechanical strength of pure magnesium in vivo, the trial failed only $8 \mathrm{~d}$ after the surgery. ${ }^{21}$

Aluminum $(\mathrm{Al})$, zinc, calcium $(\mathrm{Ca})$, manganese $(\mathrm{Mn})$, zirconium $(\mathrm{Zr})$, yttrium $(\mathrm{Y})$ and rare-earth $(\mathrm{RE})$ elements are the most common elements used in magnesium alloys. ${ }^{22}$ In 1944, Troitskii and Tsitrin ${ }^{23}$ reported a study where, for the first time, magnesium alloyed with cadmium (Cd) was fabricated into plates and screws and used to secure bone fractures: 25 of 34 cases were successfully implanted and no inflammatory reaction or high serum magnesium level was observed. Alloying elements and their weight percentage in the composition of magnesium-based alloys should be selected carefully to maintain corrosion resistance and biocompatibility. The mechanical properties and corrosion resistance could be improved by aluminum significantly. ${ }^{22}$ However, excessive aluminum ions have a high toxic effect on the nervous system. ${ }^{24}$ Also, zirconium, which is added as a grain refiner in magnesium-based alloys, has been linked to breast and lung cancer. ${ }^{25}$ Zinc and calcium are two common necessary elements in the human body, and it is believed that zinc is one effective element for improving the mechanical strength of magnesium-based alloys. ${ }^{26,27}$ In addition, zinc and manganese can also enhance the corrosion resistance by avoiding the galvanic corrosion caused by nickel and iron impurities. ${ }^{28}$ One of the most attractive approaches today in fabricating a new magnesium-based alloy is to add RE elements (scandium ( $\mathrm{Sc}$ ), yttrium and all lanthanides) to the alloy system. On the other hand, their toxicity and biocompatibility is still controversial and remains as the main concern. Neodymium $(\mathrm{Nd})$, gadolinium $(\mathrm{Gd})$, yttrium and erbium (Er) are the most commonly used REs. ${ }^{29,30}$ The corrosion resistance, biocompatibility and mechanical behavior of recently reported magnesium-based alloys for use in medical implant applications are summarized in the current paper, with the mechanical properties of bone tissue and the toxicology, and pathophysiology of the alloying elements also discussed.

\section{Alloying elements}

There are several considerations for element selection in developing bio-magnesium alloys, as shown schematically in Figure 2. The process of alloying magnesium with other elements leads to an

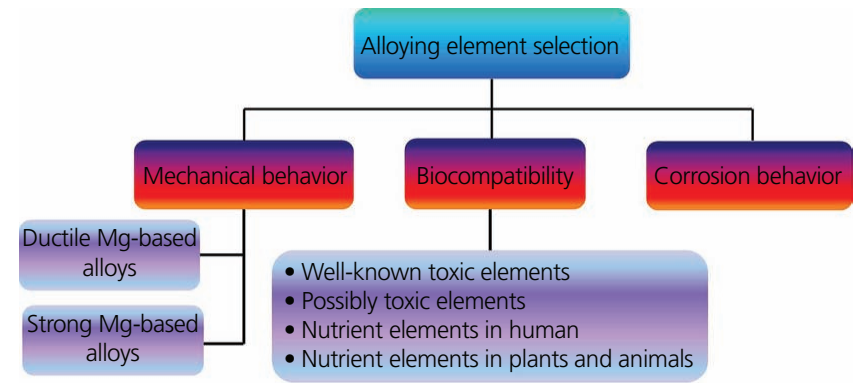

Figure 2. Considerations of element selection for developing biodegradable magnesium-based alloys
Table 1. ASTM codes for magnesium alloying elements ${ }^{31}$

$\begin{array}{llll}\text { Code } & \text { Alloying element } & \text { Code } & \text { Alloying element } \\ \text { A } & \text { Aluminum } & \text { N } & \text { Nickel } \\ \text { B } & \text { Bismuth }(\mathrm{Bi}) & \text { P } & \text { Lead }(\mathrm{Pb}) \\ \mathrm{C} & \text { Copper }(\mathrm{Cu}) & \mathrm{Q} & \text { Silver }(\mathrm{Ag}) \\ \mathrm{D} & \text { Cadmium }(\mathrm{Cd}) & \mathrm{R} & \text { Chromium }(\mathrm{Cr}) \\ \text { E } & \text { REs } & \mathrm{S} & \text { Silicon }(\mathrm{Si}) \\ \mathrm{F} & \text { Iron } & \text { T } & \text { Tin }(\mathrm{Sn}) \\ \text { H } & \text { Thorium }(\mathrm{Th}) & \mathrm{W} & \text { Yttrium } \\ \mathrm{K} & \text { Zirconium } & \mathrm{Y} & \text { Antimony }(\mathrm{Sb}) \\ \text { L } & \text { Lithium } & \text { Z } & \text { Zinc } \\ \mathrm{M} & \text { Manganese } & & \end{array}$

improvement in the corrosion resistance, biocompatibility and mechanical behavior of magnesium. ${ }^{17}$ Therefore, potential alloying elements need to be considered carefully. Magnesium alloys may contain a variety of elemental additions, as shown in Table 1. ASTM created a system for selecting and naming different elements alloyed with magnesium. The system uses two letters followed by two numbers. ${ }^{31}$ The first letter tells the element with the highest portion in the alloying addition. For example, the composition of AZ91 magnesium is approximately $9 \mathrm{wt} \%$ aluminum and $1 \mathrm{wt} \%$ zinc. Another example is WE43, which has 4 wt.\% yttrium and 3 wt.\% REs. Before discussing corrosion and biocompatibility in detail, it should be noted that different elements could also contribute to the modification of the mechanical properties of magnesium.

\section{Implantation-related mechanical properties}

Recent investigations into the application of coronary stents for commercial magnesium alloys, as shown in Figure 3(a), have opened up new opportunities for biodegradable magnesium alloys. ${ }^{32-34}$ Moreover, as shown in Figures 3(b)-3(e), another potential use for biodegradable magnesium alloys is in the manufacture of orthopedic devices, the implants for either scaffolding on which new bone can grow or fixtures holding bones together long enough to allow natural healing to take place. ${ }^{13}$ The mechanical requirements of magnesium as an implant material depend on the medical indication. During the surgical procedure of implantation, the material might be submitted to peak loads or deformations that can exceed the subsequent values during its function as an implant. For example, a cardiovascular stent is significantly deformed during the expansion of the balloon catheter. ${ }^{33}$ The struts of the stent are stretched, exceeding the limit of elasticity, and will remain permanently deformed. However, this plastic deformation should not negatively affect subsequent degradation behavior. Another example of plastic deformation during implantation is that of osteosynthesis plates that are used to fix bone fractures. The surgeon usually needs to adapt the shape of the plate to the contour of the bone. Pliers have been used to prebend bone plates, but these might leave impressions on the surface of the implant. Besides the geometrical factors of the plate, the material needs to be ductile enough to allow contouring without cracking. For bridging the fracture, the osteosynthesis plate needs to be fixed to the bone pieces. This is commonly done using 


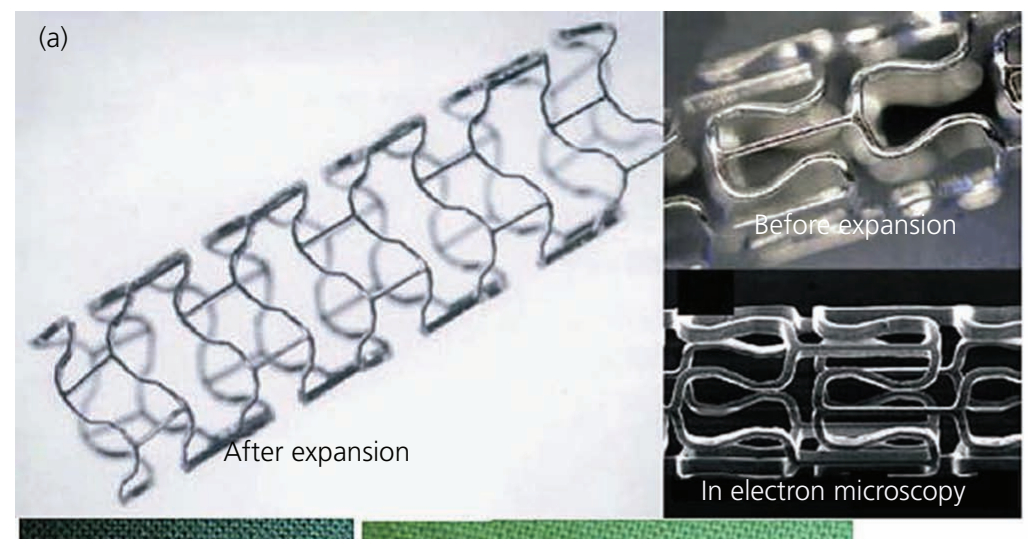

(b)
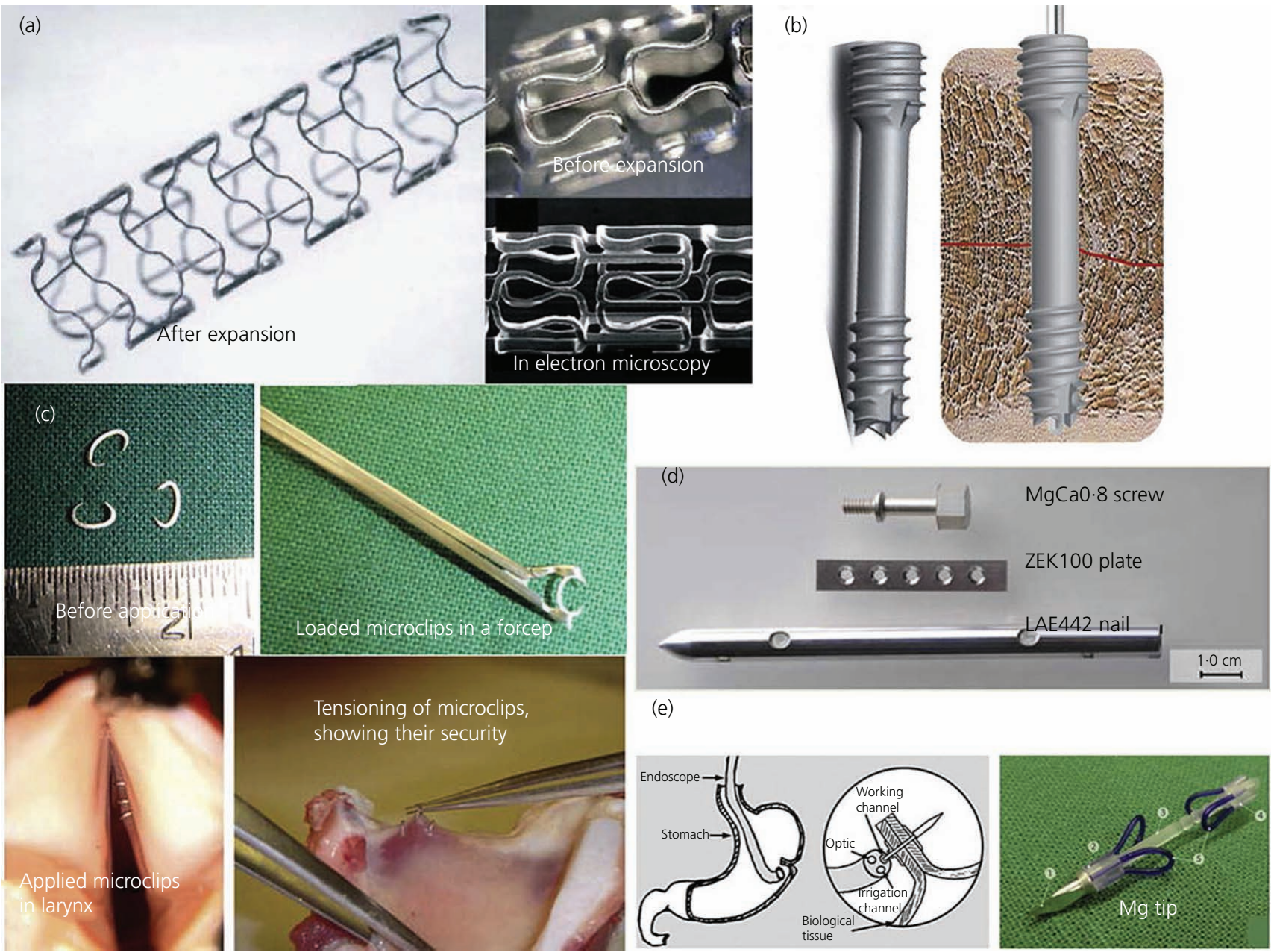

(e)
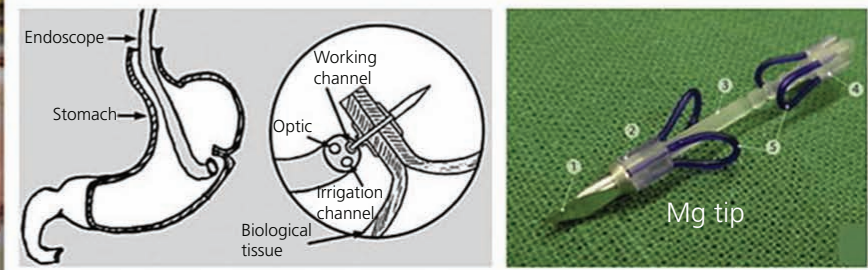

Figure 3. Real applications of biodegradable magnesium implants: (a) cardiovascular stents; (b) screws for orthopedic fixation; (c) biodegradable microclips; (d) biodegradable orthopedic implants; (e) wound-closing devices ${ }^{32}$

screws. During the insertion of the screw, the friction between the bone and the screw threads needs to be overcome. The material needs to withstand multiaxial loads (e.g. torsion, shear and compression) that are transmitted by the screwdriver. These examples show how different the mechanical requirements for a material can be during implantation. ${ }^{35}$

The use of bioabsorbable materials should allow tissues to regain their natural state and ability to transform and, in the case of children, to continue to grow. The integrity of an implant is particularly important when mechanical loads are involved. During degradation, the implant should not lose its integrity prior to the fulfillment of its mechanical function. If a failure occurs, it should be in a controlled and reproducible manner without causing unwanted side effects. The risk for the patient should always remain acceptable. ${ }^{36}$ Some typical mechanical properties of tissues and biomaterials are summarized in Table 2. Some of the alloy compositions have attracted more attention compared with others and have been tailored for specific applications.
Magnesium in its elemental state has been used, as well as other elements, including aluminum, zinc, calcium, manganese, lithium (Li), zirconium and yttrium and some of the RE metals. ${ }^{36}$ In the following sections is a general explanation of some of the most common alloying elements and their benefits.

- Aluminum. Metals alloyed with aluminum have a good combination of mechanical properties and good diecastability. Aluminum improves strength and hardness, and, when present in amounts in excess of $6 \mathrm{wt} . \%$, the alloy becomes heat-treatable. ${ }^{22,42}$

- Zinc. Similar to aluminum, zinc can improve some mechanical properties of magnesium alloys - for example, strengthening of magnesium through a solid-solutionhardening mechanism. Magnesium is frequently alloyed with zinc, which increases its yield strength. Magnesium alloys, as well as other implant materials, should have a Young's modulus of $20 \mathrm{GPa}$, which is similar to the Young's modulus of bone. ${ }^{26,36,37}$ 
Table 2. Typical mechanical properties of tissues and biomaterials ${ }^{26,36-41}$

\begin{tabular}{|c|c|c|c|c|c|c|c|}
\hline Tissue/material & $\begin{array}{l}\text { Density: } \\
\text { g/cm }\end{array}$ & $\begin{array}{l}\text { Compressive } \\
\text { strength: } \mathrm{MPa}\end{array}$ & $\begin{array}{c}\text { Tensile } \\
\text { strength: } \\
\mathrm{MPa}\end{array}$ & $\begin{array}{c}\text { Yield } \\
\text { strength: } \\
\mathrm{MPa}\end{array}$ & $\begin{array}{c}\text { Elastic } \\
\text { modulus: } \\
\text { GPa }\end{array}$ & $\begin{array}{c}\text { Fracture } \\
\text { toughness: } \\
\mathrm{MPa} \mathrm{m}^{1 / 2}\end{array}$ & $\begin{array}{l}\text { Elongation: } \\
\%\end{array}$ \\
\hline Arterial wall & $\mathrm{N} / \mathrm{A}$ & N/A & $0 \cdot 50-1 \cdot 72$ & N/A & 0.001 & $\mathrm{~N} / \mathrm{A}$ & N/A \\
\hline Collagen & N/A & N/A & 60 & N/A & $1 \cdot 0$ & N/A & N/A \\
\hline Cancellous bone & $1 \cdot 0-1 \cdot 4$ & $1 \cdot 5-9 \cdot 3$ & $1 \cdot 5-38$ & N/A & $0 \cdot 01-1 \cdot 57$ & N/A & N/A \\
\hline Cortical bone & $1 \cdot 8-2 \cdot 0$ & $\begin{array}{l}160 \text { trans. } \\
240 \text { long. }\end{array}$ & $\begin{array}{l}35 \text { trans. } \\
283 \text { long. }\end{array}$ & N/A & $5-23$ & $3-6$ & N/A \\
\hline Hydroxyapatite & $3 \cdot 05-3 \cdot 15$ & $100-900$ & $40-200$ & N/A & $70-120$ & 0.7 & N/A \\
\hline Cobalt-chrome alloys & $7 \cdot 8$ & N/A & $450-960$ & 310 & $195-230$ & $\mathrm{~N} / \mathrm{A}$ & N/A \\
\hline Stainless steel & $7 \cdot 9$ & 170-130 & $480-620$ & N/A & $193-200$ & 50-200 & N/A \\
\hline Titanium alloys & $4 \cdot 4$ & N/A & $550-985$ & $420-780$ & $100-125$ & 55-115 & $12-16$ \\
\hline Pure magnesium (cast) & $1 \cdot 74$ & 20-115 & 90-190 & $20 \cdot 9 \pm 2 \cdot 3$ & 41 & $15-40$ & $13 \cdot 0 \pm 1 \cdot 4$ \\
\hline AZ31 (extruded) & $1 \cdot 78$ & $83-97$ & $241-260$ & $125-135$ & 45 & N/A & 7 \\
\hline AZ91D (die-cast) & $1 \cdot 81$ & 160 & 230 & 150 & 45 & $\mathrm{~N} / \mathrm{A}$ & 3 \\
\hline WE43 (extruded - T5) & $1 \cdot 84$ & $\mathrm{~N} / \mathrm{A}$ & 280 & 195 & 44 & N/A & 10 \\
\hline AM60B (die-cast) & $1 \cdot 78$ & 130 & 220 & N/A & 45 & N/A & $6-8$ \\
\hline$M g-6 Z n$ & $\mathrm{~N} / \mathrm{A}$ & $433 \cdot 76 \pm 1 \cdot 40$ & $279 \cdot 5 \pm 2 \cdot 3$ & $169 \cdot 5 \pm 3 \cdot 6$ & $42 \cdot 36 \pm 0 \cdot 1$ & $\mathrm{~N} / \mathrm{A}$ & $18 \cdot 86 \pm 0.80$ \\
\hline Mg-1Ca (cast) & $\mathrm{N} / \mathrm{A}$ & $\mathrm{N} / \mathrm{A}$ & $71 \cdot 38 \pm 3 \cdot 01$ & $\mathrm{~N} / \mathrm{A}$ & N/A & N/A & $1 \cdot 876 \pm 0 \cdot 140$ \\
\hline Mg-1Ca (rolled) & N/A & $\mathrm{N} / \mathrm{A}$ & $166 \cdot 7 \pm 3 \cdot 01$ & N/A & $\mathrm{N} / \mathrm{A}$ & N/A & $3.00 \pm 0.78$ \\
\hline Mg-1Ca (extruded) & $\mathrm{N} / \mathrm{A}$ & $\mathrm{N} / \mathrm{A}$ & $239 \cdot 63 \pm 7 \cdot 21$ & $\mathrm{~N} / \mathrm{A}$ & $135 \cdot 6 \pm 5 \cdot 4$ & N/A & $10.63 \pm 0.64$ \\
\hline $\mathrm{Mg}-0 \cdot 6 \mathrm{Ca}$ & $\mathrm{N} / \mathrm{A}$ & $273 \cdot 2 \pm 6 \cdot 1$ & N/A & $114 \cdot 4 \pm 15 \cdot 1$ & $46 \cdot 5 \pm 0 \cdot 6$ & $\mathrm{~N} / \mathrm{A}$ & N/A \\
\hline $\mathrm{Mg}-1 \cdot 2 \mathrm{Ca}$ & $\mathrm{N} / \mathrm{A}$ & $254 \cdot 1 \pm 7 \cdot 9$ & N/A & $96 \cdot 5 \pm 6 \cdot 6$ & $49 \cdot 6 \pm 0 \cdot 9$ & $\mathrm{~N} / \mathrm{A}$ & N/A \\
\hline $\mathrm{Mg}-1 \cdot 6 \mathrm{Ca}$ & $\mathrm{N} / \mathrm{A}$ & $252 \cdot 5 \pm 3 \cdot 3$ & N/A & $93 \cdot 7 \pm 7 \cdot 8$ & $54 \cdot 7 \pm 2 \cdot 4$ & N/A & N/A \\
\hline $\mathrm{Mg}-2 \cdot 0 \mathrm{Ca}$ & $\mathrm{N} / \mathrm{A}$ & $232 \cdot 9 \pm 3 \cdot 7$ & N/A & $73 \cdot 1 \pm 3 \cdot 4$ & $58 \cdot 8 \pm 1 \cdot 2$ & N/A & N/A \\
\hline $\mathrm{Mg}-2 \mathrm{Sr}$ (rolled) & $\mathrm{N} / \mathrm{A}$ & $\mathrm{N} / \mathrm{A}$ & $213 \cdot 3 \pm 17 \cdot 2$ & $147 \cdot 3 \pm 13 \cdot 1$ & N/A & N/A & $3 \cdot 15 \pm 0.30$ \\
\hline $\mathrm{Mg}-0.5 \mathrm{Ca}-0.5 \mathrm{Sr}$ & $\mathrm{N} / \mathrm{A}$ & $274 \cdot 3 \pm 7 \cdot 2$ & N/A & $\mathrm{N} / \mathrm{A}$ & N/A & N/A & N/A \\
\hline $\mathrm{Mg}-1 \cdot 0 \mathrm{Ca}-0.5 \mathrm{Sr}$ & $\mathrm{N} / \mathrm{A}$ & $274 \cdot 2 \pm 4 \cdot 0$ & N/A & N/A & N/A & N/A & N/A \\
\hline $\mathrm{Mg}-0 \cdot 1 \mathrm{Ca}-1 \cdot 0 \mathrm{Sr}$ & $\mathrm{N} / \mathrm{A}$ & $214 \cdot 5 \pm 3 \cdot 5$ & N/A & N/A & N/A & N/A & N/A \\
\hline Mg-1Zn-1Mn (cast) & N/A & N/A & 174 & 44 & N/A & N/A & 12 \\
\hline
\end{tabular}

long., longitudinal; N/A, not available; trans., transverse

- Calcium. Studies demonstrated that calcium addition improves mechanical properties, influences grain growth, serves as a grain refinement agent and improves the rollability of magnesium sheets. ${ }^{36,37}$

- Manganese. It is the most common alloying addition and is used to neutralize the effect of iron and to help modify the morphology and type of intermetallic phases. Modifications in the morphology improve tensile strength, elongation and ductility. Manganese alloying addition also increases hightemperature strength and creep resistance. ${ }^{36,43}$

- Lithium. The addition of lithium decreases strength but increases ductility. Magnesium-lithium alloys are also amenable to age hardening. ${ }^{44}$

- Other RE metals. These have a powerful grain-refining effect on magnesium-based alloys. Addition of the REs increases strength and die-castability. ${ }^{29,30,36}$

Magnesium implants could offer additional benefits compared with existing implant materials. They might replace permanent metallic implants for indications in which degradation is a significant advantage. Thus, considering the matching of mechanical properties, magnesium-based materials are the best choice for biodegradable orthopedic implants. Yield strength, tensile strength and elongation are the three most common factors for determining if the material could fulfill its function from a mechanical perspective. ${ }^{36}$
The grain sizes of the alloys, second-phase distribution, mechanical properties and the absence of structural defects are strongly related to the processing routes. ${ }^{35}$ Pure magnesium and other alloying elements are typically melted and cast under an inert environment. As-casted alloys often have an inhomogeneous grain structure, which results in lower mechanical strength and fast corrosion at the grain boundary. ${ }^{35,36}$ Optical micrographs of magnesium-calcium and magnesium-calcium-manganese-zinc alloys are shown in Figures 4(a)-4(d). Zinc has a relatively high solubility in magnesium $(6.2 \mathrm{wt.} \%)$ and can play dual roles in both solid solutions and can refine the grain size. As shown in Figures 4(a)-4(d), zinc can significantly refine the microstructure of magnesium-calcium-manganese-zinc alloy. However, the mechanical properties of the binary magnesium-calcium alloys decreased significantly with the addition of $4 \mathrm{wt} . \%$ calcium. However, after the addition of zinc and manganese into the binary $\mathrm{Mg}-2 \mathrm{Ca}$ alloys, the ultimate tensile strength and elongation were enhanced by about 31.5 and $64.9 \%$, respectively (Figure $4(\mathrm{e})$ ). ${ }^{45}$ Zhang et al. $^{46}$ estimated the effects of extrusion and heat treatment on magnesium-based alloy systems. It was shown that extrusion can significantly improve the mechanical properties of an alloy by grain refinement and precipitation strengthening. ${ }^{46}$ Wang et al. ${ }^{47}$ showed that grain refinement may be a proper route for controlling the degradation rate of the magnesium alloy AZ31 in Hanks' solution. The samples were processed by squeeze- 

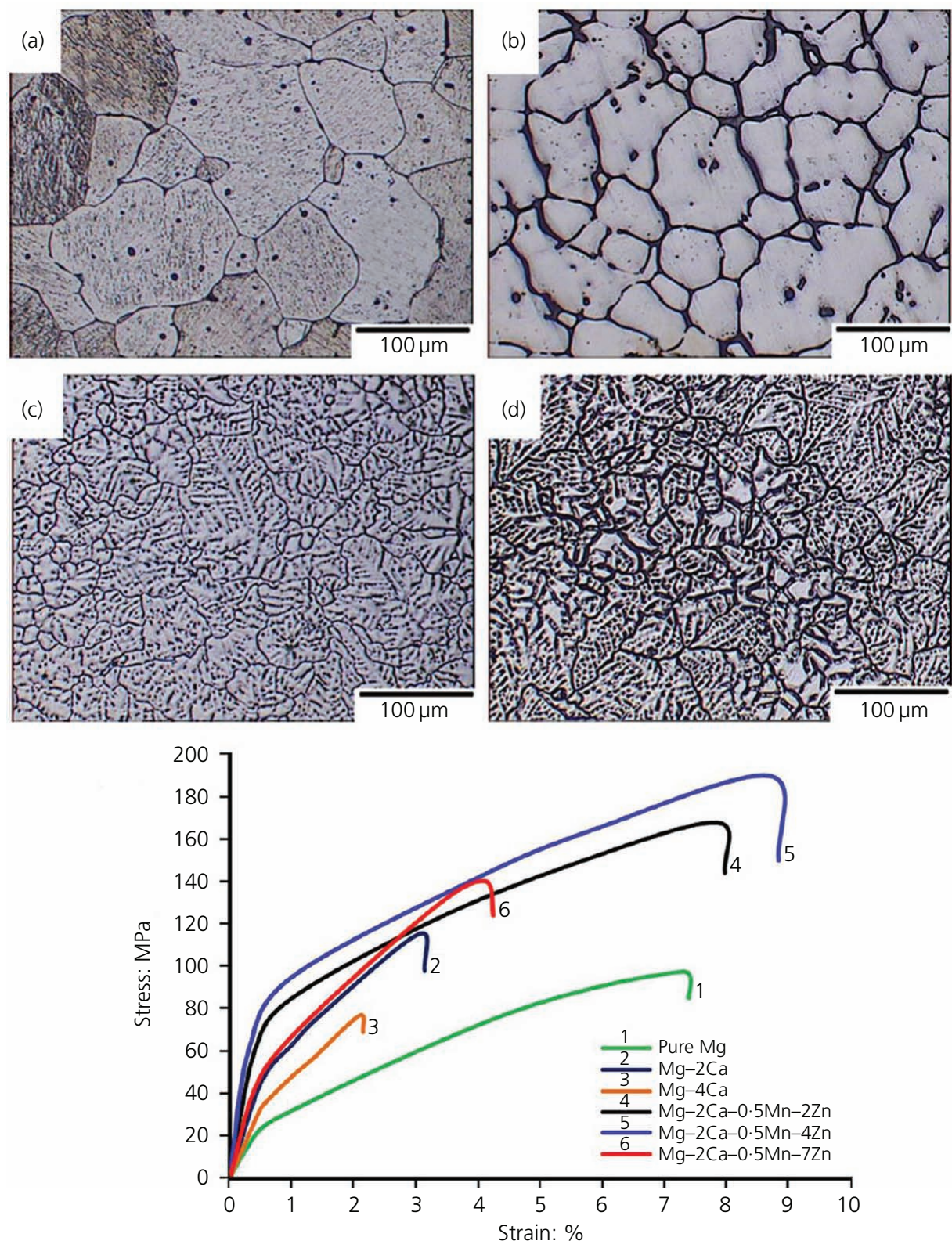

(e)

Figure 4. Optical microscopic images of specimens: (a) Mg-2Ca; (b) Mg-4Ca; Mg-0.5Ca-0.5Mn-Zn alloys with different zinc contents: (c) 2 and (d) 4 wt.\%. (e) Typical stress-strain curve of as-cast pure magnesium, magnesium-calcium and magnesium-calcium-manganese-zinc alloys ${ }^{45}$

casting (SC), hot-rolling (HR) and equal-channel angular pressing (ECAP). The degradation rates of the HR- and ECAP-processed samples with fine grains $(\sim 10 \mu \mathrm{m})$ were only about $50 \%$ of the coarse-grained $(\sim 400 \mu \mathrm{m})$ SC sample. However, fine grains alone would not increase the degradation rate. ${ }^{47}$

\section{Corrosion and bio-corrosion of magnesium-based alloys}

According to Figure 2, the alloying elements have a direct influence on the corrosion resistance of biodegradable magnesium-based alloys. Corrosion of magnesium and its alloys has been studied by researchers due to their strong thermodynamic tendency to act as active materials, with high oxidation. ${ }^{36}$ Among metals, magnesium demonstrates a very low standard potential as seen in Table $3 .{ }^{48}$ The dissimilitude of standard potential against corrosion potential is related to the formation of a magnesium hydroxide $\left(\mathrm{Mg}(\mathrm{OH})_{2}\right)$ film on the surface of the metal. It has been reported, an insulating layer of $\mathrm{Mg}(\mathrm{OH})_{2}$ forms on the surface in aqueous environments and this protects the metal from further rapid corrosion. ${ }^{28,35}$ Inorganic/ organic components, such as amino acids, proteins and chloride $\left(\mathrm{Cl}^{-}\right)$ions, can influence the corrosion rate and degradation of 
Table 3. Standard reduction potentials ${ }^{48}$

$\begin{array}{lcc}\text { Electrode } & \text { Reaction } & \text { Potential: V } \\ \text { Lithium, lithium ion }\left(\mathrm{Li}^{+}\right) & \mathrm{Li}^{+}+\mathrm{e}^{-} \rightarrow \mathrm{Li} & -3 \cdot 02 \\ \text { Potassium }(\mathrm{K}) \text {, potassium ion }\left(\mathrm{K}^{+}\right) & \mathrm{K}^{+}+\mathrm{e}^{-} \rightarrow \mathrm{K} & -2 \cdot 92 \\ \text { Sodium }(\mathrm{Na}) \text {, sodium ion }\left(\mathrm{Na}^{+}\right) & \mathrm{Na}^{+}+\mathrm{e}^{-} \rightarrow \mathrm{Na} & -2 \cdot 71 \\ \text { Magnesium, magnesium ion }\left(\mathrm{Mg}^{2+}\right) & \mathrm{Mg}^{2+}+2 \mathrm{e}^{-} \rightarrow \mathrm{Mg} & -2 \cdot 37 \\ \text { Aluminum, aluminum ion }\left(\mathrm{Al}^{3+}\right) & \mathrm{Al}^{3+}+3 \mathrm{e}^{-} \rightarrow \mathrm{Al} & -1 \cdot 71 \\ \text { Zinc, zinc ion }\left(\mathrm{Zn}^{2+}\right) & \mathrm{Zn}^{2+}+2 \mathrm{e}^{-} \rightarrow \mathrm{Zn} & -0 \cdot 76 \\ \text { Iron, iron (II) ion }\left(\mathrm{Fe}^{2+}\right) & \mathrm{Fe}^{2+}+2 \mathrm{e}^{-} \rightarrow \mathrm{Fe} & -0 \cdot 44 \\ \text { Cadmium, cadmium ion }\left(\mathrm{Cd}^{2+}\right) & \mathrm{Cd}^{2+}+2 \mathrm{e}^{-} \rightarrow \mathrm{Cd} & -0 \cdot 40 \\ \text { Nickel, nickel (II) ion }\left(\mathrm{Ni}^{2+}\right) & \mathrm{Ni}^{2+}+2 \mathrm{e}^{-} \rightarrow \mathrm{Ni} & -0 \cdot 24 \\ \text { Tin, tin (II) ion }\left(\mathrm{Sn}^{2+}\right) & \mathrm{Sn}^{2+}+2 \mathrm{e}^{-} \rightarrow \mathrm{Sn} & -0 \cdot 14 \\ \text { Copper, copper (II) ion }\left(\mathrm{Cu}^{2+}\right) & \mathrm{Cu}^{2+}+2 \mathrm{e}^{-} \rightarrow \mathrm{Cu} & 0 \cdot 34\end{array}$

magnesium alloys. Due to the corrosion activity of magnesium alloys, mechanical integrity can be affected before the specific tissue has the appropriate time to heal without any negative effects. Hard-tissue implantation repairs may require at least 12 weeks. Magnesium and its alloys corrode in aqueous solutions, and the different oxidation-reduction reactions are affected by the different alloying elements. Alloying elements that have a close electrochemical potential to, or that form intermetallic phases with a similar potential to, magnesium $(-2.37 \mathrm{~V})$ can improve corrosion resistance by reducing the internal galvanic corrosion. Such elements include yttrium, $-2.37 \mathrm{~V}$; neodymium, $-2.43 \mathrm{~V}$; and cerium $(\mathrm{Ce}),-2 \cdot 48 \mathrm{~V}^{49}$

Typically, the corrosion of magnesium produces hydrogen gas $\left(\mathrm{H}_{2}\right)$ and magnesium hydroxide. The hydroxide ions produced through the cathodic reaction cause an increase in the $\mathrm{pH}$ of the solution. The common anodic and cathodic reactions are expressed as follows. ${ }^{25}$

1. $\mathrm{Mg} \rightarrow \mathrm{Mg}^{2+}+2 \mathrm{e}^{-}$anodic reaction

\section{2. $2 \mathrm{H}_{2} \mathrm{O}+2 \mathrm{e}^{-} \rightarrow \mathrm{H}_{2}+2\left(\mathrm{OH}^{-}\right)$cathodic reaction}

3. $\mathrm{Mg}+2 \mathrm{H}_{2} \mathrm{O} \rightarrow \mathrm{Mg}(\mathrm{OH})_{2}+\mathrm{H}_{2}$ net reaction

Figure 5(a) depicts the potential-pH diagram (Pourbaix) for magnesium; the diagram helps visualize the effects on potentials of $\mathrm{pH}$ and how these affect the thermodynamic regions of corrosion, immunity and passivity. ${ }^{50}$ Furthermore, at low $\mathrm{pH}$ values, the corrosion potential resembles the region where hydrogen is stable. This leads to the production of hydrogen, which leads to the dissolution of magnesium. Similarly, it can be seen that there is a strong hydrogen evolution against dissolved oxygen $\left(\mathrm{O}_{2}\right)$; however, it is not significant. ${ }^{31} \mathrm{~A}$ major drawback of magnesium is the production of hydrogen gas when placed in contact with physiological environments. Hydrogen evolution may lead to gas pocket formation, causing necrosis within tissues and delayed healing at the surgery region area. On the other hand, if hydrogen gas is evolved at a slow rate, it can be tolerated and released by the body system. According to Noviana et al., ${ }^{51}$ a hydrogen evolution rate of $0.01\left(\mathrm{ml} / \mathrm{cm}^{2}\right) / \mathrm{d}$ can be tolerated by the human body. However, recent research has shown that hydrogen gas can be exchanged rapidly through the skin and/or accumulate in fatty tissue. Therefore, hydrogen gas adjacent to an implant (Figures 5(b) and 5(c)) may not be of major concern; it is better to eliminate it by improving the material itself. $^{51}$ One successful strategy to overcoming this problem is to fabricate metal glasses with high zinc content, particularly above the zinc-alloying threshold. ${ }^{52}$

As previously mentioned, magnesium alloys exhibit different corrosion rates depending on the alloying element that they contain. Magnesium-aluminum-zinc (AZ alloys) are the most common category of magnesium alloys. There are different opinions about the role of aluminum on the corrosion resistance of magnesium alloys. Lunder et al. ${ }^{53}$ observed that, when the aluminum content reaches $8 \%$ (mass fraction), the corrosion resistance of magnesium alloys improves at a noticeable level. Warner et al ${ }^{54}$ reported that even $5 \%$ addition of aluminum in magnesium alloys is beneficial in improving their corrosion resistance, whereas Hermann et al. ${ }^{55}$ indicated that $9 \%$ and above aluminum is helpful in improving the corrosion resistance of magnesium alloys.

Li et al. $^{39}$ studied the influence of calcium amount and chloride concentration in corroding media on the corrosion behavior of magnesium-calcium alloys. A negative shift of about $-0 \cdot 1 \mathrm{~V}$ in the open-circuit potential was observed with increasing chloride concentration in the electrolyte for all the investigated alloys. Polarization curves showed that, with increasing amount of calcium in the alloy, the mixed corrosion potential $\left(E_{\text {corr }}\right)$ became more noble or positive. The magnitude of the corrosion current density $\left(I_{\text {corr }}\right)$ also changed with calcium content, and, the higher the calcium content was, the larger the current density became. Sodium chloride $(\mathrm{NaCl})$ concentration showed a similar effect, and an increased amount of chloride led to higher corrosion current densities and corrosion rates. Kannan and Raman ${ }^{56}$ examined the degradation behavior and mechanical integrity of calciumcontaining magnesium alloys using electrochemical techniques and slow-strain-rate tests, respectively, in modified simulated body fluid 

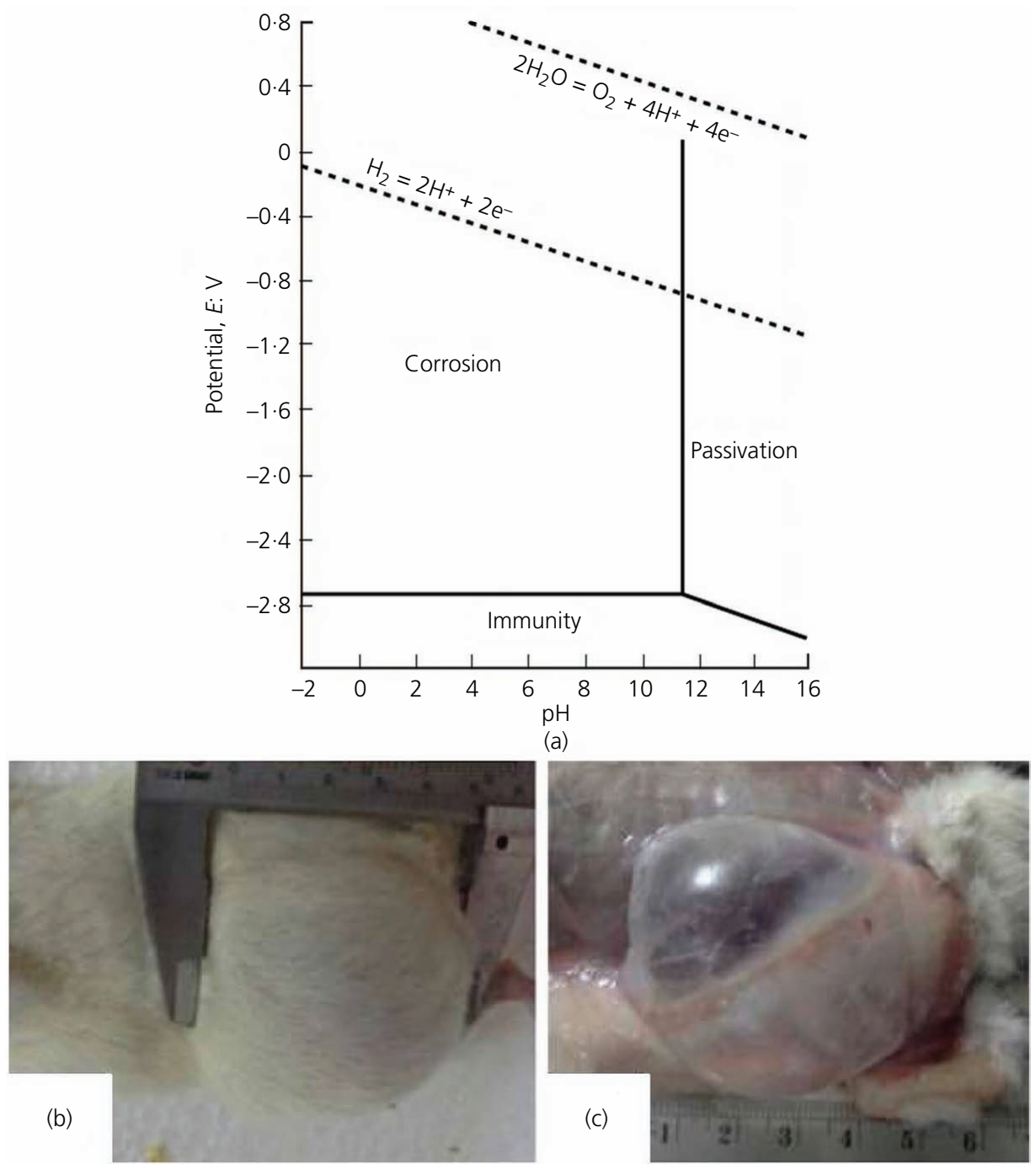

Figure 5. (a) Potential-pH (Pourbaix) diagram for the system of magnesium and water at $25^{\circ} \mathrm{C},{ }_{i}^{50}$ (b) gas bubble at the medial area; (c) subcutaneous opening of the medial area at day 7 postimplantation of pure magnesium ${ }^{51}$

(m-SBF). AZ91Ca (1.0 wt.\% calcium), AZ61Ca $\quad(0 \cdot 4$ wt.\% calcium) and AZ91 (without calcium) were used. Potentiodynamic polarization tests were performed at $36.5 \pm 0.5^{\circ} \mathrm{C}$ in $\mathrm{m}-\mathrm{SBF}$ buffered at $7 \cdot 4$. The general and pitting corrosion resistance of calcium-containing magnesium alloys in m-SBF was significantly improved compared with that of the base alloy. The corrosion current was significantly lower in AZ91Ca alloy than that in AZ91 alloy. Furthermore, AZ91Ca alloy exhibited a fivefold increase in surface film resistance relative to AZ91 alloy. ${ }^{56}$ Manganese can improve corrosion resistance by removing iron and other heavymetal elements into relatively harmless intermetallic compounds. The best anticorrosion property is obtained with $1 \mathrm{wt} \%$ zinc, while a further increase in zinc content deteriorates the corrosion property. An in vivo study showed that, after 18 weeks, about 54\% as-cast magnesium-manganese-zinc (Mg-1.2Mn-1.0Zn, in wt.\%) implant had degraded, but the degradation of magnesium did not cause any increase in serum magnesium content or any disorders of the kidney after 15 weeks postimplantation. ${ }^{36}$ The addition of silver (Ag) to magnesium alloys often results in an increase in the corrosion rate of magnesium alloys. As shown in potentiodynamic polarization curves in Figure 6, the self-corrosion potential of $\mathrm{Mg}-\mathrm{Zn}-\mathrm{Y}-\mathrm{Nd}-x \mathrm{Ag}$ shows a decreasing trend with the increase in silver content. Silver has a much higher self-corrosion potential than magnesium. ${ }^{27}$ The addition of silver results in more microgalvanic cells between the $\alpha$-magnesium matrix and the magnesium/silver second phase in the alloys, which would accelerate the corrosion rate of the alloys. In addition, it is evident that the corrosion resistance is clearly decreased due to the smaller dimensions of the capacitive loops in the Nyquist plot. ${ }^{57} \mathrm{Gu}$ et al. ${ }^{58}$ also found higher corrosion rates for both as-cast and as-rolled $\mathrm{Mg}-1 \mathrm{Ag}$ compared with pure magnesium, calculated from electrochemical measurements and immersion tests. Nevertheless, the generated hydrogen was lesser and the $\mathrm{pH}$ value of the $\mathrm{Mg}-1 \mathrm{Ag}$ sample was lower than those of pure magnesium. ${ }^{58}$ 


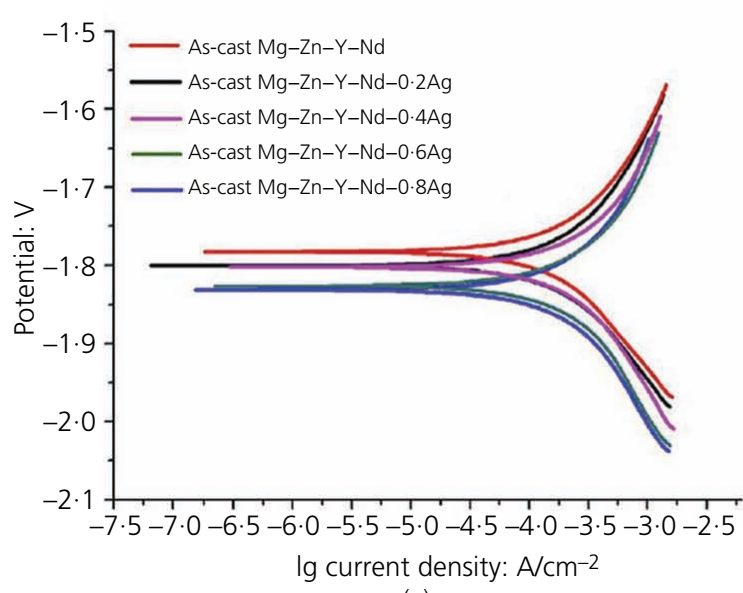

(a)

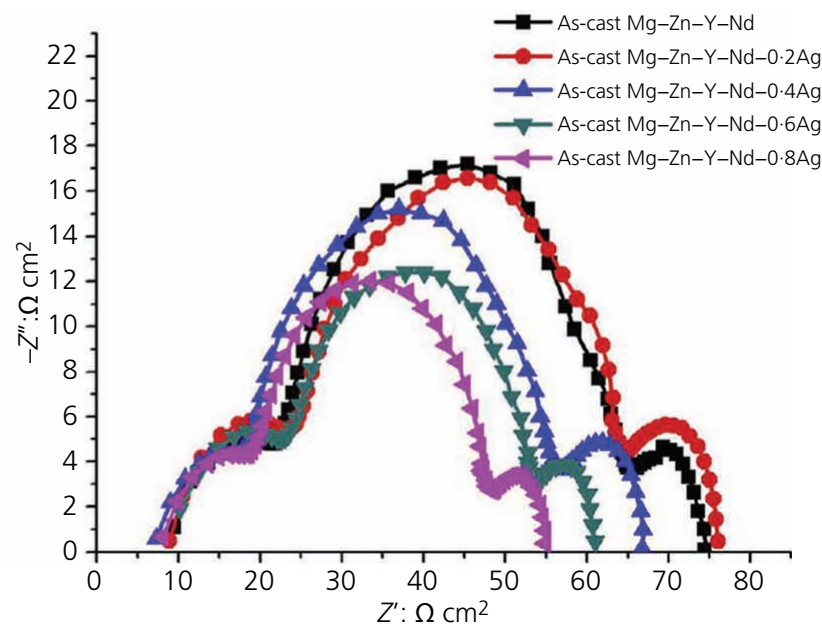

(b)

Figure 6. (a) Potentiodynamic polarization curves and (b) electrochemical impedance spectroscopy of as-cast magnesium-zinc-yttrium-neodymium and its alloys with different silver contents ${ }^{55}$

The corrosion resistance of magnesium-RE alloys $(\mathrm{RE}=\mathrm{yttrium}$, gadolinium, terbium ( $\mathrm{Tb})$, dysprosium (Dy), holmium (Ho), erbium, thulium (Tm)) was investigated by Hort et al. ${ }^{59}$ They conducted immersion tests in aerated $1 \%$ sodium chloride solution. They reported that, with increasing gadolinium up to $10 \mathrm{wt} . \%$ for the as-cast condition, the corrosion rate decreased. The Mg-15Gd values, which had a higher gadolinium amount, led to a drastic increase in the corrosion rate. Hort et al. ${ }^{59}$ explained that, compared with other binary alloys, the fraction of the grain boundaries was larger for the $15 \mathrm{wt} . \%$ gadolinium alloy. They also noted that the nickel content in $\mathrm{Mg}-15 \mathrm{Gd}$ was the highest observed. ${ }^{59}$ Immersion in SBF and Hanks' balanced salt solution (HBSS), electrochemical corrosion tests and in vitro cell cultures are often used to determine corrosion properties and biocompatibility. Table 4 summarizes the electrochemical corrosion tests of different bio-magnesium-based alloys. Sample size and corrosion solution in different experiments varied, which could have direct effects on the degradation rate.

Finally, the alloying elements have a direct influence on the corrosion resistance of magnesium-based alloys. Aluminum, zinc, manganese, zirconium and most the REs, including neodymium and gadolinium, have been proven to improve corrosion resistance. It should be noted that most elements have a critical limit with regard to their improvement of corrosion resistance that falls within their solubility in magnesium: beyond the critical limit, further addition leads to the deterioration of the corrosion resistance. ${ }^{36}$ Figure 7 shows the corrosion rate and mass loss of several kinds of magnesium alloys in physiological solution. ${ }^{49}$

Sometimes it is difficult to improve corrosion resistance without sacrificing the mechanical performance of an alloy. ${ }^{62,63}$ In this case, surface modification or treatment is a favorable option, because surface modification or treatment occurs only on the surface layer of a magnesium alloy and the bulk alloy is left unchanged. Several techniques have been developed and used for this purpose. For example, plasma electrolytic oxidation coatings are one of the simplest approaches that can effectively passivate the surface without reducing the bulk performance of a material. ${ }^{64-69}$ An overview of the different techniques used for developing coatings on magnesium and magnesium alloy substrates is shown in Figure 8.

Table 4. Electrochemical corrosion tests of magnesium alloys $36,45,60,61$

\begin{tabular}{|c|c|c|c|c|c|c|}
\hline Alloy & Shape & Area: $\mathrm{cm}^{2}$ & Solution & $I_{\text {corr: }}: \mathrm{mA} / \mathrm{cm}^{2}$ & $E_{\text {corr }}: \mathbf{V}$ & Degradation rate: $\mathrm{mm} /$ year \\
\hline Pure magnesium & Square & 1 & HBSS & 0.0598 & $-1 \cdot 554$ & $\mathrm{~N} / \mathrm{A}$ \\
\hline AZ31 & Round & 0.785 & SBF & $0 \cdot 182$ & $-1 \cdot 54$ & N/A \\
\hline WE43 & Round & 1 & SBF & 0.509 & $-1 \cdot 85$ & $\mathrm{~N} / \mathrm{A}$ \\
\hline Magnesium-lithium-aluminum & Round & 0.785 & HBSS & $0 \cdot 418-1 \cdot 412$ & -1.482 to -1.587 & $0 \cdot 1-3 \cdot 4$ \\
\hline Magnesium-zinc-calcium & Square & 1 & SBF & $0 \cdot 11$ & $-1 \cdot 645$ & N/A \\
\hline $\mathrm{Mg}-0.5$ strontium $(\mathrm{Sr})$ & N/A & $0 \cdot 72$ & HBSS & 0.005 & $-1 \cdot 58$ & $0 \cdot 2-0 \cdot 4$ \\
\hline Magnesium-zinc-yttrium-neodymium & Round & 1 & SBF & 1.08 & $-1 \cdot 7$ & $\mathrm{~N} / \mathrm{A}$ \\
\hline Magnesium-neodymium-zinc-zirconium & Round & 1 & HBSS & 0.00141 & $-1 \cdot 69$ & N/A \\
\hline Magnesium-zinc-yttrium & N/A & 1 & SBF & 0.44 & $-1 \cdot 792$ & N/A \\
\hline Magnesium-lithium & Round & 0.785 & HBSS & $0 \cdot 428-0 \cdot 461$ & -1.52 to -1.565 & $0 \cdot 1-0 \cdot 16$ \\
\hline
\end{tabular}

N/A, not available 


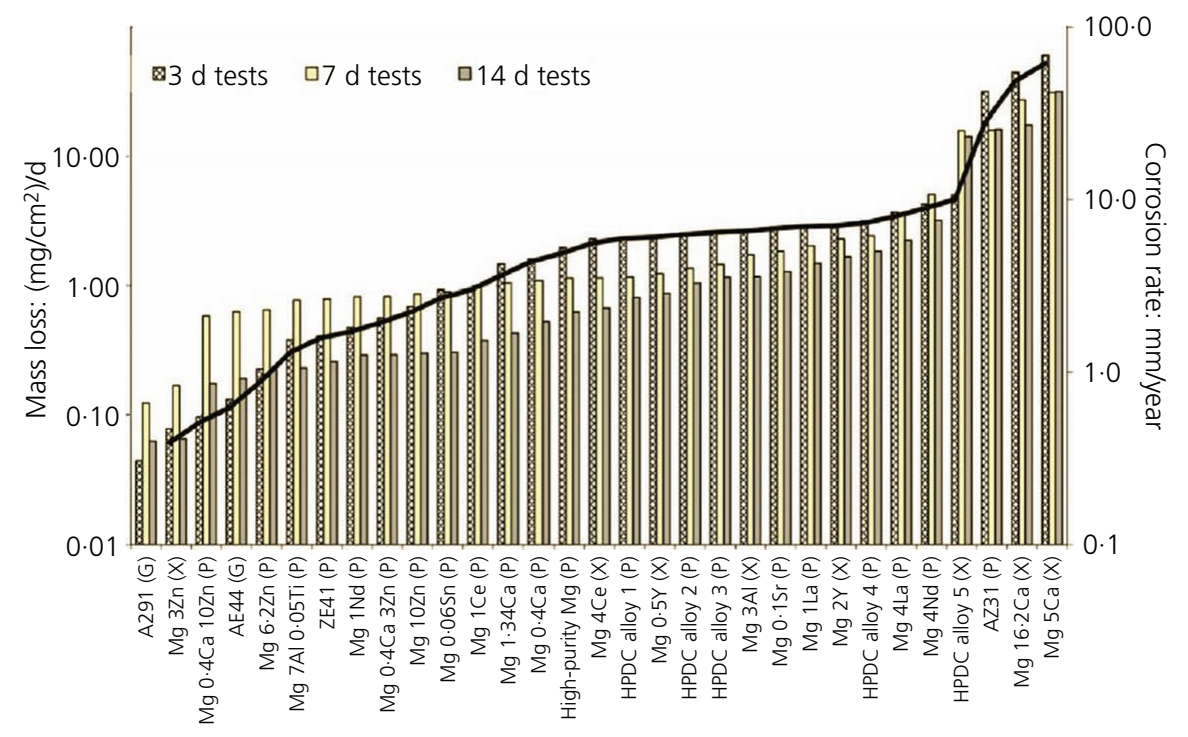

Figure 7. Experimentally determined corrosion rates for different magnesium alloys. The notation ' $G$ ' refers to alloys that suffered a general corrosion mode; ' $P$ ' refers to the pitting corrosion mode; and ' $X$ ' refers to extremely localized corrosion. HPDC, high-pressure die-cast ${ }^{49}$

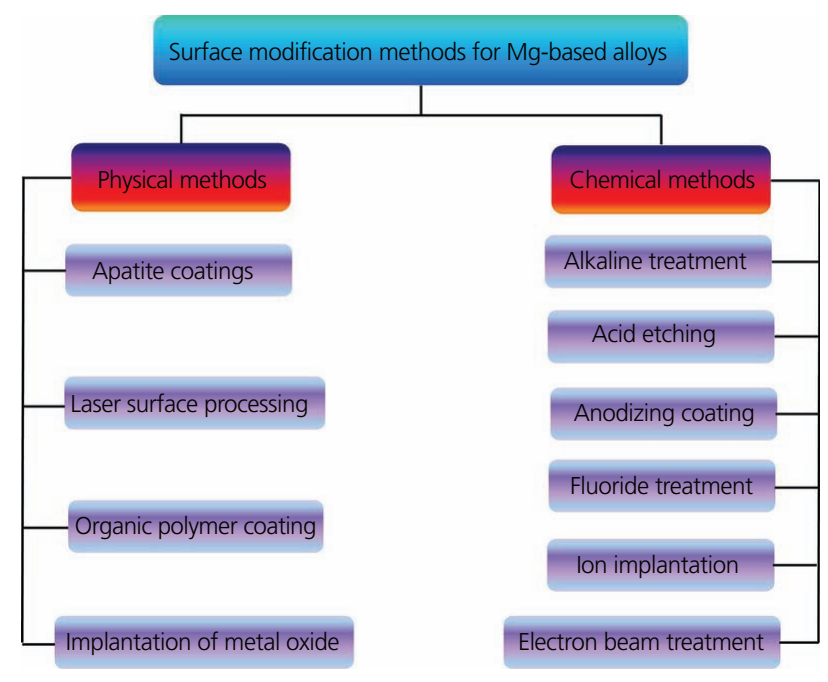

Figure 8. Main strategies of surface modification techniques for magnesium and its alloys as orthopedic implants

\section{Biocompatibility of magnesium alloys and cytotoxicity of alloying elements}

In order to employ implants successfully inside the body, good interaction between metals and living organisms is necessary; in other words, a high degree of biocompatibility is required. The term 'biocompatibility' indicates the ability of a material to perform with an appropriate host response. No adverse effects are acceptable, or the material should not affect local and systemic host environments, such as soft tissues, bone, the ionic composition of plasma and even intra- and extra-cellular fluids. ${ }^{70}$ In other words, materials intended for medical use should be non-carcinogenic, non-pyrogenic, nontoxic, non-allergic, non-inflammatory and hemocompatible. ${ }^{70}$
Magnesium is an essential divalent intracellular cation that plays a pivotal role in daily physiological functions within the body. In fact, magnesium is necessary for the synthesis of nucleic acids and proteins and is critical in the production and function of various enzymes and transporters. Also, magnesium is vital to metabolic processes, being a cofactor in many enzymes stabilizing the structures of deoxyribonucleic acid (DNA) and ribonucleic acid (RNA) and a key component of ribosomal machinery that translates the genetic information encoded by messenger RNA into polypeptide structures. $^{71}$ There are approximately $22-26 \mathrm{~g}$ of magnesium within the adult human body, and it is the fourth most abundant cation. ${ }^{72}$ On the other hand, excess magnesium can lead to muscular paralysis, hypotension, respiratory distress and cardiac arrest, all found to be unlikely because of efficient filtration by the kidneys. In vitro and in vivo studies have shown that magnesium alloys possess good biocompatibility. ${ }^{73}$

Alloying elements not only enhance the corrosion and mechanical behavior of magnesium alloys, but also impart significant effects on its biocompatibility. ${ }^{36}$ In vitro tests are often performed for evaluation of potential effects of the material on the host organism before implantation. These experiments are simulated in a physiological environment in the laboratory and in test tubes. In order to start evaluating and testing a material, cytotoxicity tests should be performed. $^{72,74}$ There are various in vitro approaches that are employed to examine biomaterials and cell behavior. The material is tested by performing direct-contact and indirect-contact experiments. The most common methods for biomaterial screening are cytotoxicity assays and cell proliferation. To illustrate, Figure 9 shows the viability of murine fibroblast cells L-929 expressed as a percentage of the viability of cells cultured in negative control after cultured in as-cast pure magnesium and $\mathrm{Mg}-1 X$ alloys extraction medium solutions for 2 and $4 \mathrm{~d}$. It can be seen that, for L-929 fibroblasts, the 


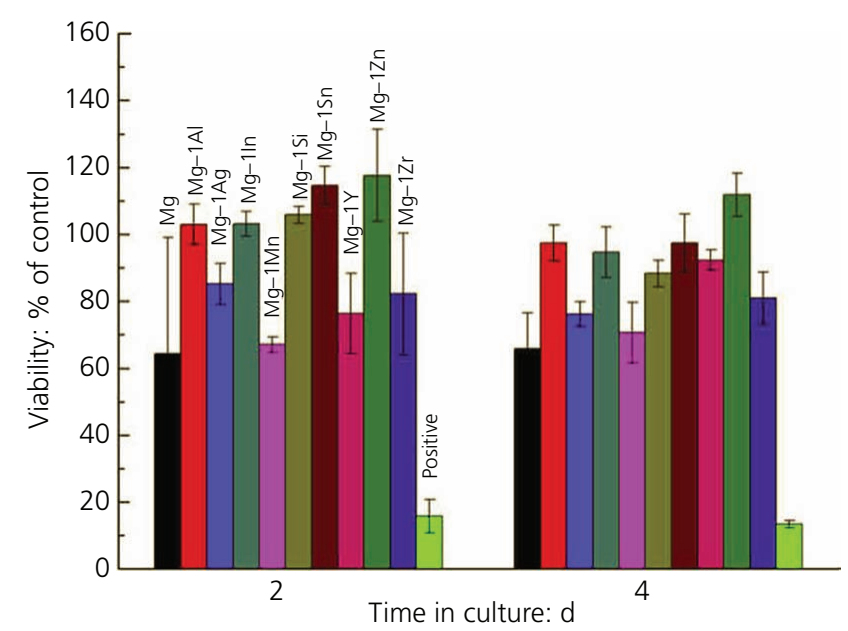

Figure 9. Cell viability expressed as a percentage of the viability of cells in the control after 2, 4 and $7 \mathrm{~d}$ of culture in as-cast pure magnesium and $\mathrm{Mg}-1 X$ alloy $(X=$ aluminum, silver, indium $(\mathrm{In})$, manganese, silicon, tin, yttrium, zinc and zirconium) extraction media ${ }^{75}$ extracts of pure magnesium and $\mathrm{Mg}-1 \mathrm{Ag}, \mathrm{Mg}-1 \mathrm{In}, \mathrm{Mg}-1 \mathrm{Mn}$, $\mathrm{Mg}-1 \mathrm{Si}, \mathrm{Mg}-1 \mathrm{Y}$ and $\mathrm{Mg}-1 \mathrm{Zr}$ alloys lead to significantly reduced cell viability $(p<0.05)$ in comparison with negative controls for the 4 d culture. $^{75}$

Furthermore, tests in vivo play an important role in providing understanding of the sample behavior under in-service conditions. All research works until now have reported enhanced new bone formation around the implants of magnesium alloys and enhanced local periosteal and endosteal bone formation in the vicinity. Degradation product layer on experimental magnesium alloy implants revealed a high deposition of calcium phosphate $\left(\mathrm{PO}_{4}{ }^{3-}\right)$ based mineral. The design of the implants also influences the corrosion of the implants. The most common orthopedic implant designs used in animal models are either screw type (threaded) or cylindrical (rod-shaped). ${ }^{76}$ Screw-type implants provide good initial stability, and analysis of rod-shaper or cylindrical implants may be less complicated, and the exact fit into the bone gives accurate results regarding their effect on bone integration. ${ }^{77}$ Lee et al. ${ }^{78}$ investigated the bone formation mechanism of a biodegradable
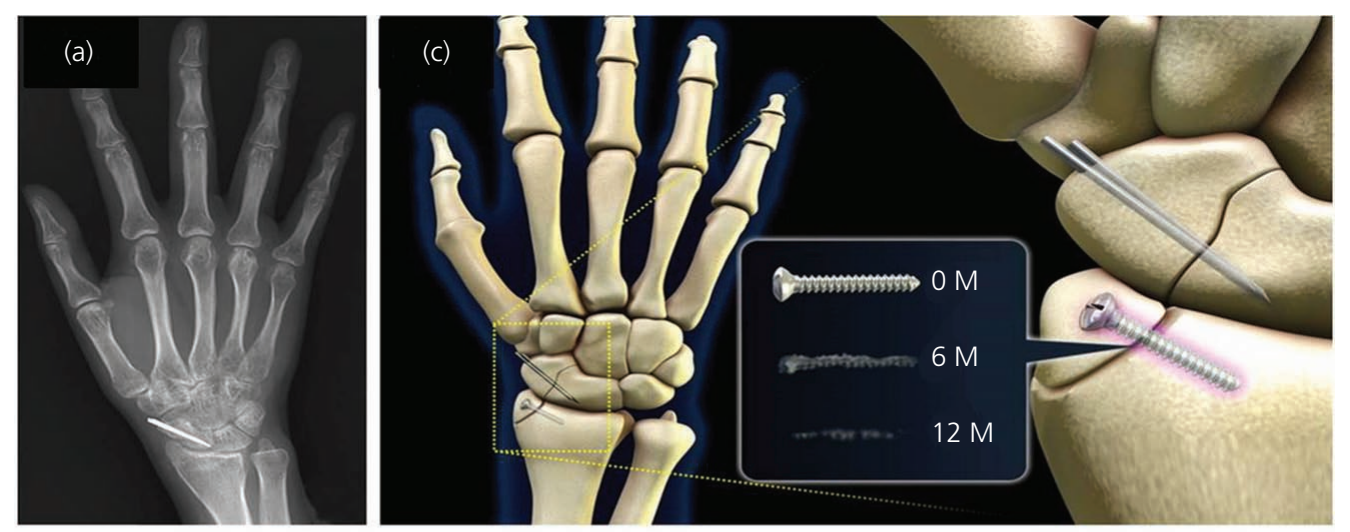

(b)
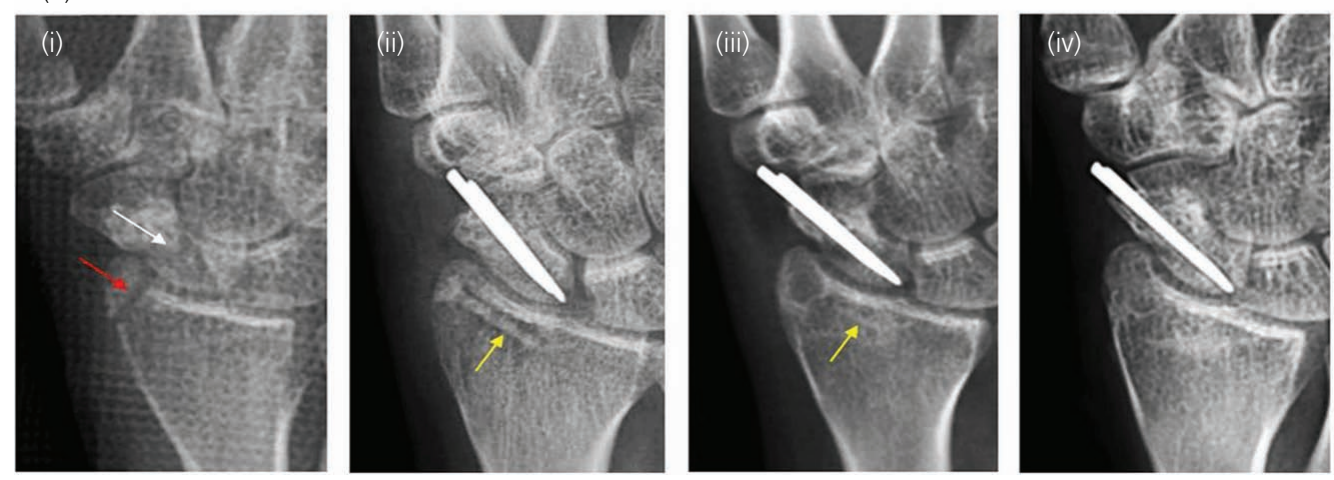

Figure 10. Clinical observation of the radiographic images of selected 1-year follow-up of a 29-year-old female patient. (a) A 1-year follow-up X-ray of the patient that received a magnesium alloy implant $(D 2.3 \mathrm{~mm} \times L 14 \mathrm{~mm})$ for distal radius fracture and a stainlesssteel conventional implant (Cl) for scaphoid non-union. (b) X-ray images of (i) the distal radius fracture and the scaphoid non-union before the surgical intervention; (ii) the implantation site immediately taken after the surgical procedures to fix the distal radius fracture with the magnesium alloy implant and the scaphoid non-union with Cl; (iii) the 6-month follow-up; and (iv) complete degradation and bone healing after 1 year postoperation. The red arrow shows the distal radius fracture, and the white arrow points to the scaphoid non-union. The yellow arrows show the magnesium alloy implant. (c) Schematic diagram showing the implantation site and the change in the magnesium alloy over time: immediately $(0 \mathrm{M})$, after 6 months $(6 \mathrm{M})$ and after 12 months $(12 \mathrm{M})$ after implantation ${ }^{78}$ 
magnesium-5 wt.\% calcium-1 wt.\% zinc alloy implant. Biodegradable magnesium-5 wt.\% calcium-1 wt. $\%$ zinc alloy screws were implanted in vivo and were gradually degraded within 26 weeks, and new formation of bone was observed. Figure 10 shows radiographic images of a selected 1-year follow-up of the 29year-old female patient. The 1-year follow-up, including clinical, laboratory and radiographic assessments, revealed that the degradable magnesium-based screws showed good to excellent clinical and radiographic results with a high satisfaction rate. No foreign body reaction, osteolysis, systemic inflammatory reaction, palpable gas cavity and significant elevations in blood magnesium levels are observed. ${ }^{78}$ According to Figure 2, the degradation products of the designed alloys should be non-toxic and absorbable by the surrounding tissues or dissolvable for excretion through the kidneys Elements can be classified into the following groups: (a) well-known toxic elements: beryllium (Be), barium $(\mathrm{Ba})$, lead $(\mathrm{Pb})$, cadmium and thorium $(\mathrm{Th}) ;(b)$ elements that are likely to cause severe hepatotoxicity or other allergic problems in humans: aluminum, vanadium $(\mathrm{V})$, chromium $(\mathrm{Cr})$, cobalt, nickel, copper $(\mathrm{Cu})$, lanthanum $(\mathrm{La})$, cerium amd praseodymium $(\operatorname{Pr}) ;(c)$ nutrient elements found in the human body: calcium, manganese, zinc, tin $(\mathrm{Sn})$ and silicon $(\mathrm{Si})$; and $(d)$ nutrient elements found in plants and animals: aluminum, bismuth (Bi), lithium, silver, strontium ( $\mathrm{Sr}$ ) and zirconium. ${ }^{36,75,79-81}$ For example, animal studies have found excessive exposure to aluminum toxicity to result in a variety of problems, including those affecting reproduction, inducing dementia and potentially leading to Alzheimer's disease (although data are not conclusive for humans). ${ }^{82}$ Table 5 summarizes the pathophysiology and toxicology of the three categories magnesium and the commonly used alloying elements: potential essential metals, an essential nutrient and the other common alloying elements. ${ }^{83}$

\section{Conclusion}

The main purpose of this study is to review and compare the mechanical properties, corrosion properties and biocompatibilities of currently researched magnesium alloys for biomedical applications. Magnesium alloys, as a new kind of degradable biomaterials, have attracted great attention recently. The major advantages of magnesium alloys as temporary biomaterials are their good mechanical properties and biocompatibility. (a) Magnesium and magnesium alloys are exceptionally lightweight metals with densities ranging from 1.74 to $1.85 \mathrm{~g} / \mathrm{cm}^{3}$, which is much lower than that of biomedical titanium alloys $\left(4 \cdot 4-4 \cdot 5 \mathrm{~g} / \mathrm{cm}^{3}\right)$ and close to that of the bone $\left(1 \cdot 8-2 \cdot 1 \mathrm{~g} / \mathrm{cm}^{3}\right)$. (b) The fracture toughness of magnesium is greater than that of ceramic biomaterials, while the elastic modulus (41-45 GPa) is close to that of the bone, avoiding the stress-shielding effect. (c) Magnesium is essential to human metabolism and is the fourth most abundant cation in the human body, with an estimated $25 \mathrm{~g}$ magnesium stored in the human body and approximately half of the total content stored in bone tissue. Magnesium is a cofactor for many enzymes and stabilizes the structures of DNA and RNA. (d) Magnesium has a standard electrode potential of $-2.37 \mathrm{~V}$, and bare magnesium metal exhibits even poorer corrosion resistance in the chloride-ion-containing physiological environment. Therefore, magnesium alloys could be developed as new biodegradable metals, taking advantage of their fast corrosion rate in the physiological environment. Alloying elements can be added to increase the strength and corrosion resistance of pure magnesium,

Table 5. Summary of the pathophysiology and toxicology of magnesium and commonly used alloying elements ${ }^{83}$

\begin{tabular}{|c|c|c|c|c|c|}
\hline Element & $\begin{array}{l}\text { Amount in } \\
\text { the human } \\
\text { body }\end{array}$ & $\begin{array}{l}\text { Blood } \\
\text { serum } \\
\text { level }\end{array}$ & Pathophysiology & Toxicology & $\begin{array}{l}\text { Daily } \\
\text { allowance }\end{array}$ \\
\hline Magnesium & $25 \mathrm{~g}$ & $0.9 \mathrm{mmol} / \mathrm{l}$ & $\begin{array}{l}\text { Activator of many enzymes; coregulator of protein } \\
\text { synthesis and muscle contraction; stabilizer of DNA and } \\
\text { RNA }\end{array}$ & $\begin{array}{l}\text { Almost no evidence indicates } \\
\text { toxicity of magnesium }\end{array}$ & $0.7 \mathrm{~g}$ \\
\hline Aluminum & $<300 \mathrm{mg}$ & $2 \cdot 1-4 \cdot 8 \mu g$ & - & $\begin{array}{l}\text { Neurotoxic and accumulates } \\
\text { in bone }\end{array}$ & - \\
\hline Zinc & $2 \mathrm{~g}$ & $46 \mu \mathrm{mol} / /$ & Essential trace element; appears in all enzyme classes & $\begin{array}{l}\text { Neurotoxic and hinders bone } \\
\text { development at higher } \\
\text { concentration }\end{array}$ & $15 \mathrm{mg}$ \\
\hline Calcium & $1100 \mathrm{~g}$ & $1 \cdot 3 \mathrm{mmol} / \mathrm{l}$ & $\begin{array}{l}\text { Most abundant mineral and mainly stored in bone and } \\
\text { teeth; participates in blood clotting; activator or } \\
\text { stabilizer of enzymes }\end{array}$ & $\begin{array}{l}\text { Calcium metabolism } \\
\text { disorder; kidney stones }\end{array}$ & $0.8 \mathrm{~g}$ \\
\hline Manganese & $12 \mathrm{mg}$ & $1 \mu \mathrm{mol} / \mathrm{l}$ & $\begin{array}{l}\text { Essential trace element; activator of enzymes; manganese } \\
\text { deficiency is related to osteoporosis, diabetes mellitus } \\
\text { and atherosclerosis }\end{array}$ & $\begin{array}{l}\text { Excessive manganese results } \\
\text { in neurotoxicity }\end{array}$ & $4 \mathrm{mg}$ \\
\hline Zirconium & $<250 \mathrm{mg}$ & $\begin{array}{l}\text { Total } \\
<250 \mathrm{mg}\end{array}$ & 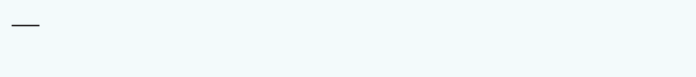 & $\begin{array}{l}\text { High concentration in liver } \\
\text { and gall bladder }\end{array}$ & $3 \cdot 5 \mathrm{mg}$ \\
\hline Lithium & - & $2-4 \mathrm{ng} / \mathrm{g}$ & Used in the treatment of manic-depressive psychoses & $\begin{array}{l}\text { Reduced kidney function and } \\
\text { central nervous system } \\
\text { disorders }\end{array}$ & $0.2-0.6 \mathrm{mg}$ \\
\hline $\begin{array}{l}\text { Yttrium } \\
\text { and REs }\end{array}$ & - & $<47 \mu g$ & Compound of drugs for treatment of cancer & $\begin{array}{l}\text { Accumulation in bone } \\
\text { and liver }\end{array}$ & - \\
\hline Silicon & - & - & $\begin{array}{l}\text { Cross-linking agent of connective tissue base membrane } \\
\text { structures; necessary for growth and bone calcification }\end{array}$ & $\begin{array}{l}\text { Excessive silicon dioxide } \\
\qquad\left(\mathrm{SiO}_{2}\right) \text { causes lung diseases }\end{array}$ & - \\
\hline
\end{tabular}


but alloying elements should be selected carefully to maintain magnesium's biocompatibility. Most commercial magnesium alloys contain aluminum and RE; however, aluminum is a neurotoxicant and severe hepatotoxicity has been detected after the administration of RE. Therefore, another research highlight is the exploration of new magnesium alloy systems containing non-toxic or low-toxicity elements. However, there is a lack of uniform criteria for evaluating the biomedical properties of magnesium alloys.

\section{Acknowledgements}

This study was supported by the Materials and Energy Research Center. The authors would like to thank many colleagues, students and collaborators who have made a vast contribution to this area of research.

\section{REFERENCES}

1. Wang X, Xu S, Zhou S et al. (2016) Topological design and additive manufacturing of porous metals for bone scaffolds and orthopaedic implants: a review. Biomaterials 83: 127-141.

2. Rahmati M and Mozafari M (2019) Biocompatibility of aluminabased biomaterials - a review. Journal of Cellular Physiology 234(4): 3321-3335.

3. Touri M, Kabirian F, Saadati M, Ramakrishna S and Mozafari M (2019) Additive manufacturing of biomaterials - the evolution of rapid prototyping. Advanced Engineering Materials 21(2), article 1800511.

4. Su Y, Luo C, Zhang Z et al. (2018) Bioinspired surface functionalization of metallic biomaterials. Journal of the Mechanical Behavior of Biomedical Materials 77: 90-105.

5. Yang Y, Qiao L, Gao Z and Yan Y (2016) Study of wear-corrosion resistance of Co-based biomaterial. Emerging Materials Research 5(2): 194-200, https://doi.org/10.1680/jemmr.16.00102.

6. Shirdar MR, Izman S, Kheimehsari HM, Ahmad N and Ma'aram A (2017) Evaluation of mechanical and electrochemical properties of FHA-coated Co-Cr implant. Surface Innovations 5(2): 90-96, https:// doi.org/10.1680/jsuin.16.00028.

7. Movassagh-Alanagh F, Abdollah-Zadeh A, Aliofkhazraei $\mathrm{M}$ and Abedi M (2017) Improving the wear and corrosion resistance of Ti-6Al-4V alloy by deposition of TiSiN nanocomposite coating with pulsed-DC PACVD. Wear 390: 93-103.

8. Movassagh-Alanagh F, Abdollah-zadeh A, Asgari M and Ghaffari MA (2018) Influence of Si content on the wettability and corrosion resistance of nanocomposite TiSiN films deposited by pulsed-DC PACVD. Journal of Alloys and Compounds 739: 780-792.

9. Naghib SM, Ansari M, Pedram A et al. (2012) Bioactivation of 304 stainless steel surface through 45S5 bioglass coating for biomedical applications. International Journal of Electrochemical Science 7: 2890-2903.

10. Joshi MG, Advani SG, Miller F and Santare MH (2000) Analysis of a femoral hip prosthesis designed to reduce stress shielding. Journal of Biomechanics 33(12): 1655-1662.

11. Staiger MP, Pietak AM, Huadmai J and Dias G (2006) Magnesium and its alloys as orthopedic biomaterials: a review. Biomaterials 27(9): 1728-1734.

12. Chen $Q$ and Thouas GA (2015) Metallic implant biomaterials. Materials Science and Engineering: R: Reports 87: 1-57.

13. Böstman $\mathrm{O}$ and Pihlajamäki H (2000) Clinical biocompatibility of biodegradable orthopaedic implants for internal fixation: a review. Biomaterials 21(24): 2615-2621.

14. Shomali AA, Guillory RJ, Seguin D, Goldman J and Drelich JW (2017) Effect of PLLA coating on corrosion and biocompatibility of zinc in vascular environment. Surface Innovations 5(4): 211-220, https://doi. org/10.1680/jsuin.17.00011
15. Drelich AJ, Bowen PK, LaLonde L, Goldman J and Drelich JW (2016) Importance of oxide film in endovascular biodegradable zinc stents. Surface Innovations 4(3): 133-140, https://doi.org/10.1680/jsuin.16. 00014.

16. Sillekens WH (2013) Magnesium-based biodegradable implants Emerging Materials Research 2(5): 216-218, https://doi.org/10.1680/ emr.13.00047.

17. Gill P, Munroe N and Datye A (2013) Synthesis, characterization and mechanical properties of biodegradable magnesium alloys. Emerging Materials Research 2(1): 45-52, https://doi.org/10.1680/emr.12. 00020.

18. Farraro KF, Kim KE, Woo SL, Flowers JR and McCullough MB (2014) Revolutionizing orthopaedic biomaterials: the potential of biodegradable and bioresorbable magnesium-based materials for functional tissue engineering. Journal of Biomechanics 47(9): 1979-1986.

19. Huse EC (1878) A new ligature. Chicago Medical Journal and Examiner 172(2): 171-172.

20. Witte $F$ (2010) The history of biodegradable magnesium implants: a review. Acta Biomaterialia 6(5): 1680-1692.

21. Singh Raman RK and Choudhary L (2013) Cracking of magnesiumbased biodegradable implant alloys under the combined action of stress and corrosive body fluid: a review. Emerging Materials Research 2(5): 219-228, https://doi.org/10.1680/emr.13.00033.

22. Agarwal S, Curtin J, Duffy B and Jaiswal S (2016) Biodegradable magnesium alloys for orthopaedic applications: a review on corrosion, biocompatibility and surface modifications. Materials Science and Engineering: C 68: 948-963.

23. Troitskii VV and Tsitrin DN (1944) The resorbing metallic alloy 'Osteosinthezit' as material for fastening broken bone. Khirurgiia 8(1): 41-44.

24. Yokel RA (2000) The toxicology of aluminum in the brain: a review. Neurotoxicology 21(5): 813-828.

25. Song G (2007) Control of biodegradation of biocompatable magnesium alloys. Corrosion Science 49(4): 1696-1701.

26. Smith CE, Xu Z, Waterman J and Sankar J (2013) Cytocompatibility assessment of $\mathrm{MgZnCa}$ alloys. Emerging Materials Research 2(5): 283-290, https://doi.org/10.1680/emr.13.00026.

27. Törne KB, Khan FA, Örnberg A and Weissenrieder J (2017) Zn-Mg and $\mathrm{Zn}-\mathrm{Ag}$ degradation mechanism under biologically relevant conditions. Surface Innovations 6(1-2): 81-92, https://doi.org/10 1680/jsuin.17.00053.

28. Ye CH, Zheng YF, Wang SQ, Xi TF and Li YD (2012) In vitro corrosion and biocompatibility study of phytic acid modified WE43 magnesium alloy. Applied Surface Science 258(8): 3420-3427.

29. Seitz JM, Fau DR, Eifler $\mathrm{R}$ et al. (2013) $\mathrm{MgNd}_{2}$ : a future resorbable magnesium-based implant material? Emerging Materials Research 2(5): 239-247, https://doi.org/10.1680/emr.13.00034.

30. Feyerabend F, Fischer J, Holtz J et al. (2010) Evaluation of short-term effects of rare earth and other elements used in magnesium alloys on primary cells and cell lines. Acta Biomaterialia 6(5): 1834-1842.

31. ASTM (2008) and B 951-08: Standard practice for codification of unalloyed magnesium and magnesium-alloys, cast and wrought. ASTM International, West Conshohocken, PA, USA.

32. Chen Y, Xu Z, Smith C and Sankar J (2014) Recent advances on the development of magnesium alloys for biodegradable implants. Acta Biomaterialia 10(11): 4561-4573.

33. Bowen PK, Drelich J, Buxbaum RE, Rajachar RM and Goldman J (2012) New approaches in evaluating metallic candidates for bioabsorbable stents. Emerging Materials Research 1(5): 237-255, https://doi.org/10.1680/emr.12.00017.

34. Aggarwal A, Jenkins CS, Mangla J, Shanley CJ and Long GW (2014) Innovations in vascular device surface engineering: a clinical review. Surface Innovations 2(1): 3-16, https://doi.org/10.1680/si.13.00022.

35. Ghasali E, Bordbar-Khiabani A, Alizadeh M et al. (2019) Corrosion behavior and in-vitro bioactivity of porous $\mathrm{Mg} / \mathrm{Al}_{2} \mathrm{O}_{3}$ and $\mathrm{Mg} / \mathrm{Si}_{3} \mathrm{~N}_{4}$ 
metal matrix composites fabricated using microwave sintering process. Materials Chemistry and Physics 225: 331-339.

36. Li N and Zheng Y (2013) Novel magnesium alloys developed for biomedical application: a review. Journal of Materials Science \& Technology 29(6): 489-502.

37. Zhang E, Yin D, Xu L, Yang L and Yang K (2009) Microstructure, mechanical and corrosion properties and biocompatibility of $\mathrm{Mg}-\mathrm{Zn}-\mathrm{Mn}$ alloys for biomedical application. Materials Science and Engineering: C 29(3): 987-993.

38. Poinern GEJ, Brundavanam S and Fawcett D (2012) Biomedical magnesium alloys: a review of material properties, surface modifications and potential as a biodegradable orthopaedic implant. American Journal of Biomedical Engineering 2(6): 218-240.

39. Li Z, Gu X, Lou S and Zheng Y (2008) The development of binary $\mathrm{Mg}-\mathrm{Ca}$ alloys for use as biodegradable materials within bone. Biomaterials 29(10): 1329-1344.

40. Wan Y, Xiong G, Luo H et al. (2008) Preparation and characterization of a new biomedical magnesium-calcium alloy. Materials \& Design 29(10): 2034-2037.

41. Zhang S, Zhang X, Zhao C et al. (2010) Research on an Mg-Zn alloy as a degradable biomaterial. Acta Biomaterialia 6(2): 626-640.

42. Yang Z, Li JP, Zhang JX, Lorimer GW and Robson J (2008) Review on research and development of magnesium alloys. Acta Metallurgica Sinica 5(21): 313-328.

43. Kwas E, Schmidt J, Kunert M and Thein S (2017) Ceramic coatings containing calcium and phosphate on magnesium alloy MnE21. Surface Innovations 5(4): 221-231, https://doi.org/10.1680/jsuin.17. 00017

44. Chang TC, Wang JY, Chu CL and Lee S (2006) Mechanical properties and microstructures of various $\mathrm{Mg}-\mathrm{Li}$ alloys. Materials Letters 60(27): 3272-3276.

45. Bakhsheshi-Rad HR, Idris MH, Abdul-Kadir MR et al. (2014) Mechanical and bio-corrosion properties of quaternary $\mathrm{Mg}-\mathrm{Ca}-\mathrm{Mn}-\mathrm{Zn}$ alloys compared with binary $\mathrm{Mg}-\mathrm{Ca}$ alloys. Materials \& Design 53: 283-292.

46. Zhang X, Yuan G, Mao L et al. (2012) Effects of extrusion and heat treatment on the mechanical properties and biocorrosion behaviors of a $\mathrm{Mg}-\mathrm{Nd}-\mathrm{Zn}-\mathrm{Zr}$ alloy. Journal of the Mechanical Behavior of Biomedical Materials 7: 77-86.

47. Wang H, Estrin Y and Zúberová Z (2008) Bio-corrosion of a magnesium alloy with different processing histories. Materials Letters 62(16): 2476-2479.

48. Chen Q, Li J and Li Y (2015) A review of plasma-liquid interactions for nanomaterial synthesis. Journal of Physics D: Applied Physics 48(42): article 424005

49. Kirkland NT, Lespagnol J, Birbilis N and Staiger MP (2010) A survey of bio-corrosion rates of magnesium alloys. Corrosion Science 52(2) $287-291$.

50. Shetty S, Nayak J and Shetty AN (2015) Influence of sulfate ion concentration and $\mathrm{pH}$ on the corrosion of $\mathrm{Mg}-\mathrm{Al}-\mathrm{Zn}-\mathrm{Mn}$ (GA9) magnesium alloy. Journal of Magnesium and Alloys 3(3): 258-270.

51. Noviana D, Paramitha D, Ulum MF and Hermawan H (2016) The effect of hydrogen gas evolution of magnesium implant on the postimplantation mortality of rats. Journal of Orthopaedic Translation 5: 9-15.

52. Witte F, Kaese V, Haferkamp H et al. (2005) In vivo corrosion of four magnesium alloys and the associated bone response. Biomaterials 26(17): 3557-3563.

53. Lunder O, Lein JE, Aune TK and Nisancioglu K (1989) The role of $\mathrm{Mg} 17 \mathrm{Al12}$ phase in the corrosion of Mg alloy AZ91. Corrosion 45(9): 741-748.

54. Warner TJ, Thorne NA, Nussbaum G and Stobbs WM (1992) A crosssectional TEM study of corrosion initiation in rapidly solidified $\mathrm{Mg}$ based ribbons. Surface and Interface Analysis 19(1-12): 386-392.

55. Hermann F, Sommer F, Jones H and Edyvean RGJ (1989) Corrosion inhibition in magnesium-aluminium-based alloys induced by rapid solidification processing. Journal of Materials Science 24(7): 2369-2379.

56. Kannan MB and Raman RS (2008) In vitro degradation and mechanical integrity of calcium-containing magnesium alloys in modified-simulated body fluid. Biomaterials 29(15): 2306-2314.

57. Feng $Y$, Zhu S, Wang L et al. (2018) Fabrication and characterization of biodegradable $\mathrm{Mg}-\mathrm{Zn}-\mathrm{Y}-\mathrm{Nd}-\mathrm{Ag}$ alloy: microstructure, mechanical properties, corrosion behavior and antibacterial activities. Bioactive Materials 3(3): 225-235.

58. Gu X, Zheng Y, Cheng Y, Zhong S and Xi T (2009) In vitro corrosion and biocompatibility of binary magnesium alloys. Biomaterials 30(4): 484-498.

59. Hort N, Huang Y, Fechner D et al. (2010) Magnesium alloys as implant materials - principles of property design for $\mathrm{Mg}-\mathrm{RE}$ alloys. Acta Biomaterialia 6(5): 1714-1725.

60. Liu C, Xin Y, Tang G and Chu PK (2007) Influence of heat treatment on degradation behavior of bio-degradable die-cast AZ63 magnesium alloy in simulated body fluid. Materials Science and Engineering: A 456(1-2): 350-357.

61. Jaiswal S, Kumar RM, Gupta P et al. (2018) Mechanical, corrosion and biocompatibility behaviour of $\mathrm{Mg}-3 \mathrm{Zn}-\mathrm{HA}$ biodegradable composites for orthopaedic fixture accessories. Journal of the Mechanical Behavior of Biomedical Materials 78: 442-454.

62. Hornberger H, Virtanen S and Boccaccini AR (2012) Biomedical coatings on magnesium alloys - a review. Acta Biomaterialia 8(7): 2442-2455.

63. Boinovich LB, Emelyanenko AM, Pashinin AS et al. (2013) Mg alloy treatment for superhydrophobic anticorrosion coating formation. Surface Innovations 1(3): 162-172, https://doi.org/10.1680/si.13. 00001.

64. Zhang J, Zhang L, Wilke BM et al. (2017) Corrosion behaviour of microarc-oxidised magnesium alloy in Earle's balanced salt solution. Surface Innovations 5(1): 43-53, https://doi.org/10.1680/jsuin.16. 00019.

65. Khiabani AB, Ghanbari A, Yarmand B et al. (2018) Improving corrosion behavior and in vitro bioactivity of plasma electrolytic oxidized AZ91 magnesium alloy using calcium fluoride containing electrolyte. Materials Letters 212: 98-102.

66. Bordbar-Khiabani A, Yarmand B and Mozafari M (2018) Functional PEO layers on magnesium-alloys: innovative polymer-free drug eluting surfaces. Surface Innovations 6(4-5): 237-243, https://doi.org/ 10.1680/jsuin.18.00011.

67. Khiabani AB, Rahimi S, Yarmand B and Mozafari M (2018) Electrophoretic deposition of graphene oxide on plasma electrolytic oxidized-magnesium implants for bone tissue engineering applications. Materials Today: Proceedings 5(7): 15603-15612.

68. Ghanbari A, Khiabani AB, Zamanian A, Yarmand B and Mozafari M (2018) The competitive mechanism of plasma electrolyte oxidation for the formation of magnesium oxide bioceramic coatings. Materials Today: Proceedings 5(7): 15677-15685.

69. Bordbar-Khiabani A, Yarmand B and Mozafari M (2019) Enhanced corrosion resistance and in-vitro biodegradation of plasma electrolytic oxidation coatings prepared on AZ91 Mg alloy using $\mathrm{ZnO}$ nanoparticles-incorporated electrolyte. Surface and Coatings Technology 360: 153-171.

70. Bordbar-Khiabani A, Ebrahimi S and Yarmand B (2018) Plasma electrolytic oxidation of monocrystalline silicon using silicate electrolyte containing boric acid. Applied Surface Science 462: 913-922.

71. Sepahvandi A, Moztarzadeh F, Mozafari M et al. (2011) Photoluminescence in the characterization and early detection of biomimetic bone-like apatite formation on the surface of alkalinetreated titanium implant: state of the art. Colloids and Surfaces B: Biointerfaces 86(2): 390-396. 
72. Schille C, Schweizer E, Hort N, Reichel HP and Geis-Gerstorfer J (2013) Zone coulometry and ion-release analysis of degradable magnesium alloys. Emerging Materials Research 2(5): 248-262, https://doi.org/10.1680/emr.13.00023.

73. Niederlaender J, Rudi P, Schweizer E et al. (2013) Cytocompatibility of magnesium alloys with adult human endothelial cells. Emerging Materials Research 2(5): 274-282, https://doi.org/10.1680/emr.13.00014.

74. Nguyen A, Kunert M, Hort N et al. (2015) Cytotoxicity of the Gacontaining coatings on biodegradable magnesium alloys. Surface Innovations 3(1): 10-19, https://doi.org/10.1680/si.13.00035.

75. Gu X, Zheng Y, Cheng Y, Zhong S and Xi T (2009) In vitro corrosion and biocompatibility of binary magnesium alloys. Biomaterials 30(4): 484-498.

76. Latham B and Goswami T (2004) Effect of geometric parameters in the design of hip implants paper IV. Materials \& Design 25(8): 715-722.

77. Park HS, Jeong SH and Kwon OW (2006) Factors affecting the clinical success of screw implants used as orthodontic anchorage. American Journal of Orthodontics and Dentofacial Orthopedics 130(1): 18-25.
78. Lee JW, Han HS, Han KJ et al. (2016) Long-term clinical study and multiscale analysis of in vivo biodegradation mechanism of $\mathrm{Mg}$ alloy. Proceedings of the National Academy of Sciences of the United States of America 113(3): 716-721.

79. Kargozar S, Lotfibakhshaiesh N, Ai J et al. (2017) Strontium-and cobalt-substituted bioactive glasses seeded with human umbilical cord perivascular cells to promote bone regeneration via enhanced osteogenic and angiogenic activities. Acta Biomaterialia 58: 502-514.

80. Maier P, Mendis C, Tober G and Hort N (2013) Tailoring properties of cast Mg10Gd by alloying $\mathrm{Nd}$ and heat treatment. Emerging Materials Research 2(5): 229-238, https://doi.org/10.1680/emr.13.00021.

81. Li T, He Y, Zhou J et al. (2018) Effects of scandium addition on biocompatibility of biodegradable $\mathrm{Mg}-1.5 \mathrm{Zn}-0.6 \mathrm{Zr}$ alloy. Materials Letters 215: 200-202.

82. El-Rahman SSA (2003) Neuropathology of aluminum toxicity in rats (glutamate and GABA impairment). Pharmacological Research 47(3): 189-194.

83. Zheng Y (2015) Magnesium Alloys as Degradable Biomaterials. CRC Press, Boca Raton, FL, USA.

\section{How can you contribute?}

To discuss this paper, please submit up to 500 words to the journal office at journals@ice.org.uk. Your contribution will be forwarded to the author(s) for a reply and, if considered appropriate by the editor-in-chief, it will be published as a discussion in a future issue of the journal.

ICE Science journals rely entirely on contributions from the field of materials science and engineering. Information about how to submit your paper online is available at www.icevirtuallibrary.com/page/authors, where you will also find detailed author guidelines. 